\title{
A theoretical comparison between two ruminal electron sinks
}

\section{Emilio M. Ungerfeld *}

CONICYT Regional R10C1002, Centro de Investigación y Desarrollo CIEN Austral, Universidad Austral de Chile, Puerto Montt, Chile

\section{Edited by:}

Garret Suen, University of

Wisconsin-Madison, USA

\section{Reviewed by:}

Michael Poulsen, University of Copenhagen, Denmark

Hilario C. Mantovani, Universidade

Federal de Viçosa, Brazil

Paul J. Weimer, United States

Department of Agriculture, USA

\section{*Correspondence}

Emilio M. Ungerfeld, Instituto de Investigaciones Agropecuarias Remehue, Ruta $5 \mathrm{~km} 8$ norte

Osorno, casilla de correos 24-0

Osorno, 5290000, Chile

e-mail: emilio.ungerfeld@

cienaustral.cl
Dihydrogen accumulation resulting from methanogenesis inhibition in the rumen is an energy loss and can inhibit fermentation. The objective of this analysis was to compare the energetic and nutritional consequences of incorporating $\mathrm{H}_{2}$ into reductive acetogenesis or additional propionate production beyond the acetate to propionate shift occurring along with methanogenesis inhibition. Stoichiometric consequences were calculated for a simulated fermentation example. Possible nutritional consequences are discussed. Incorporating $\mathrm{H}_{2}$ into reductive acetogenesis or additional propionate production resulted in equal heat of combustion output in volatile fatty acids (VFA). Incorporation of $\mathrm{H}_{2}$ into reductive acetogenesis could result in moderate decrease in ruminal $\mathrm{pH}$, although whole-animal buffering mechanisms make $\mathrm{pH}$ response difficult to predict. Research would be needed to compare the microbial protein production output. There could be post-absorptive implications due to differences in VFA profile. Electron incorporation into reductive acetogenesis could favor energy partition toward milk, but increase risk of ketosis in high-producing dairy cows on ketogenic diets. Greater propionate production could favor milk protein production, but may be less desirable in animals whose intake is metabolically constrained, like feedlot steers. Because of the different nutritional implications, and because practical solutions to incorporate $\mathrm{H}_{2}$ into either pathway are not yet available, it is recommended to research both alternatives.

Keywords: rumen, methane, hydrogen, fermentation, reductive acetogenesis, propionate, ruminant nutrition

\section{INTRODUCTION}

In ruminal fermentation, $\mathrm{H}_{2}$ is produced from reducing equivalents released in glycolysis and pyruvate oxidative decarboxylation to acetyl-CoA (Figure 1). Methane is the main sink for $\mathrm{H}_{2}$ electrons in the rumen (Wolin et al., 1997). Interspecies $\mathrm{H}_{2}$ transfer from the fermentative community of bacteria, protozoa and fungi to methanogens is of great significance. Methanogenesis allows maintaining a low $\mathrm{H}_{2}$ pressure, shifting fermentation away from ethanol and lactate and toward acetate, which allows extra ATP generation by substrate level phosphorylation in acetate formation, and by electron transport-linked-phosphorylation in methanogenesis itself (Russell and Wallace, 1997; Wolin et al., 1997). However, despite its profound implication to ruminal fermentation, $\mathrm{CH}_{4}$ formation constitutes a loss of between 2 and $12 \%$ of the gross energy consumed by ruminants (Attwood and McSweeney, 2008). Also, $\mathrm{CH}_{4}$ emission by livestock is an important source of anthropogenic greenhouse gases emissions (Morgavi et al., 2010).

Because of these environmental and animal production efficiency issues, considerable research on the inhibition of ruminal methanogenesis has been conducted. Inhibition of methanogenesis poses the problem of the incorporation of the electrons not used in $\mathrm{CH}_{4}$ formation into alternative pathways. As methanogenesis is inhibited, $\mathrm{H}_{2}$ pressure increases, and this thermodynamically favors electron incorporation into propionate (Figure 1; Janssen, 2010). Nevertheless, incorporation of reducing equivalents spared from methanogenesis into propionate is not complete (Czerkawski, 1986), and $\mathrm{H}_{2}$ accumulates, especially if $\mathrm{CH}_{4}$ production is strongly inhibited, whether in vitro (e.g., Trei et al., 1971; Stanier and Davies, 1981; Sauer and Teather, 1987) or in vivo (e.g., Trei et al., 1971; Nollet et al., 1998; Kung et al., 2003; Mitsumori et al., 2012).

It is therefore necessary to conduct research on the incorporation of accumulated $\mathrm{H}_{2}$ into electron sinks nutritionally useful to the animal. In order to better guide current research efforts in this area, it would be important to anticipate the outcomes of incorporating $\mathrm{H}_{2}$ into different electron sinks. The present theoretical analysis compares the hypothetical energetic and nutritional consequences of incorporating accumulated $\mathrm{H}_{2}$ into reductive acetogenesis or additional propionate formation beyond the typical acetate to propionate shift that occurs when methanogenesis is inhibited. Dihydrogen incorporation into a useful electron sink is a necessary part of an integral methanogenesis-inhibition strategy, because it minimizes gaseous digestible energy (DE) losses and avoids fermentation inhibition. Thus, it is important to predict, compare and anticipate how, not only fermentation, but whole animal digestion and metabolism, and hence production, could change if $\mathrm{H}_{2}$ was incorporated into different alternative electron sinks.

Electron-incorporating processes alternative to methanogenesis other than reductive acetogenesis and propionate production will not be considered in the present analysis. Nitrate and sulphate 
reduction (Van Zijderveld et al., 2010), and reduction of oxygen entering the rumen through the rumen wall and in feed and water (Czerkawski, 1986) do not incorporate electrons into energy sources available to ruminants (although nitrate could replace urea as a source of $\mathrm{N}$ on an equal moles of $\mathrm{N}$ basis). Long chain fatty acids biohydrogenation only uses a small proportion of metabolic hydrogen produced in fermentation (Czerkawski, 1986). Microbial biomass synthesis also requires reducing power (Hungate et al., 1961), and both theoretical considerations (Czerkawski, 1986) and in vitro results (Ungerfeld et al., 2007; Guo et al., 2009) suggests that it can be an important alternative electron sink to $\mathrm{CH}_{4}$; however, consequences of methanogenesis inhibition on microbial growth are still incompletely quantified and understood as they involve multiple anabolic pathways in a complex microbial community, and this electron sink is therefore not compared to reductive acetogenesis and propionate production in this analysis.

\section{PROCEDURES}

\section{STOICHIOMETRIC CALCULATIONS}

\section{Typical ruminal fermentation}

Both starch and cellulose are hydrolyzed to glucose; however, the fermentation pattern of starch is lower in acetate to propionate ratio compared to cellulose (Bannink et al., 2006). Because acetate production results in the release of reducing equivalents, whereas propionate production incorporates them (Figure 1), fermentation of concentrates typically associates with less $\mathrm{CH}_{4}$ produced per mol of hexose fermented, as propionate production competes with methanogenesis for reducing equivalents (Czerkawski, 1986; Wolin et al., 1997). Two typical example fermentation stoichiometries for roughage(Equation 1) and concentrate-based (Equation 2) diets are provided below. In Equation 1 (roughage), $1 \mathrm{~mol}$ of glucose is fermented to VFA and gases with 4 to 1 acetate to propionate ratio; in Equation 2 (concentrate), $1 \mathrm{~mol}$ of glucose is fermented to VFA and gases with 1.5 to 1 acetate to propionate ratio:

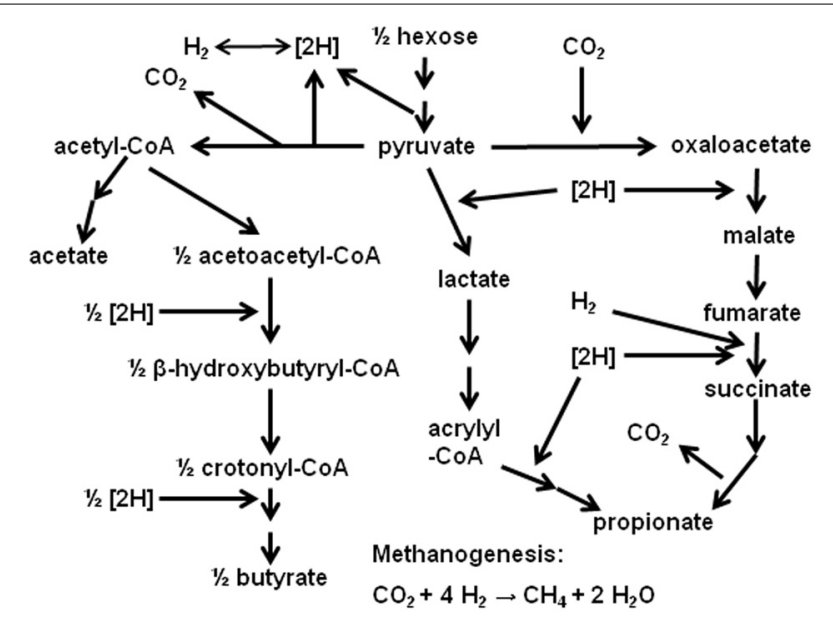

FIGURE 1 | Main ruminal fermentation pathways.

$$
\begin{aligned}
& \mathrm{C}_{6} \mathrm{H}_{12} \mathrm{O}_{6} \longrightarrow 4 / 3 \mathrm{CH}_{3} \mathrm{COO}^{-}+1 / 3 \mathrm{CH}_{3} \mathrm{CH}_{2} \mathrm{COO}^{-} \\
&+ 1 / 6 \mathrm{CH}_{3} \mathrm{CH}_{2} \mathrm{CH}_{2} \mathrm{COO}^{-}+11 / 6 \mathrm{H}^{+} \\
&+\mathrm{CO}_{2}+2 / 3 \mathrm{CH}_{4}+1 / 3 \mathrm{H}_{2} \mathrm{O} \\
& \mathrm{C}_{6} \mathrm{H}_{12} \mathrm{O}_{6} \longrightarrow 12 / 13 \mathrm{CH}_{3} \mathrm{COO}^{-}+8 / 13 \mathrm{CH}_{3} \mathrm{CH}_{2} \mathrm{COO}^{-} \\
&+3 / 13 \mathrm{CH}_{3} \mathrm{CH}_{2} \mathrm{CH}_{2} \mathrm{COO}^{-}+23 / 13 \mathrm{H}^{+} \\
&+25 / 26 \mathrm{CO}_{2}+11 / 26 \mathrm{CH}_{4}+7 / 13 \mathrm{H}_{2} \mathrm{O}
\end{aligned}
$$

Acetate to propionate ratios for high-roughage and high-concentrate diets were obtained from a compilation of 300 treatment means from 79 in vivo studies in which ruminal VFA concentrations were reported (Figure 2; Ungerfeld, unpublished). Production of valerate, caproate and branchedchain VFA are not considered for the sake of simplification. It is also important to note that VFA proportions are also affected by factors other than the chemical fraction fermented (Bannink et al., 2008).

\section{Methanogenesis-inhibited ruminal fermentation}

When methanogenesis is inhibited, reducing equivalents are diverted into alternative electron sinks. Some of these alternative electron sinks are typical to ruminal fermentation, like propionate (Czerkawski, 1986; Wolin et al., 1997; Janssen, 2010) and microbial growth (Czerkawski, 1986; Ungerfeld et al., 2007; Guo et al., 2009); in contrast, intermediate metabolites that are usually present at very low concentration or pressure, like $\mathrm{H}_{2}$ (Janssen, 2010) or format (Czerkawski, 1986), accumulate. A hypothetical situation in which methanogenesis in the roughage diet of Equation 1 is inhibited by $92 \%$ (similar extent of inhibition: Nollet et al., 1997a; Goel et al., 2009; Tomkins et al., 2009; Mitsumori et al., 2012), with resulting $\mathrm{H}_{2}$ accumulation, is represented in Equation 3:

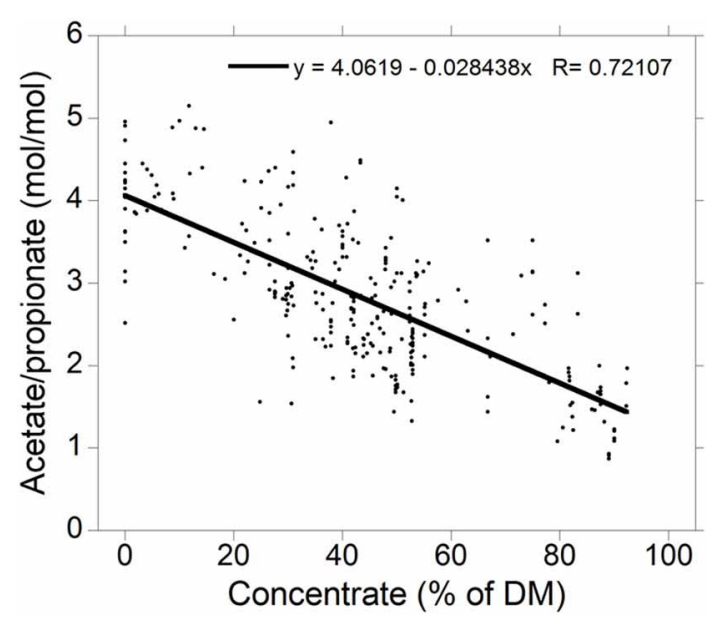

FIGURE 2 | Relationship between the acetate to propionate molar concentration ratio and the percentage of concentrate in the diet dry matter (DM) for $\mathbf{3 0 0}$ treatment means in 73 experiments (Ungerfeld, unpublished). 


$$
\begin{aligned}
& \mathrm{C}_{6} \mathrm{H}_{12} \mathrm{O}_{6}+3 / 5 \mathrm{H}_{2} \mathrm{O}+66 \mathrm{X} / 59 \longrightarrow 70 / 59 \mathrm{CH}_{3} \mathrm{COO}^{-} \\
& +28 / 59 \mathrm{CH}_{3} \mathrm{CH}_{2} \mathrm{COO}^{-}+10 / 59 \mathrm{CH}_{3} \mathrm{CH}_{2} \mathrm{CH}_{2} \mathrm{COO}^{-} \\
& +108 / 59 \mathrm{H}^{+}+867 / 590 \mathrm{CO}_{2}+264 / 295 \mathrm{H}_{2}+33 / 590 \mathrm{CH}_{4} \\
& +66 \mathrm{X}[2 \mathrm{H}] / 59
\end{aligned}
$$

The sum of electron sinks other than $\mathrm{CH}_{4}$, propionate and $\mathrm{H}_{2}$ (i.e., mainly microbial biomass and formate) are represented in Equation 3 by the term $\mathrm{X}[2 \mathrm{H}]$, accounting in this example for $32 \%$ of total electron-pairs incorporated. The shift in the acetate to propionate ratio from 4 to 1 to 2.5 to 1 in Equation 3 with respect to Equation 1 resulted in propionate formation increasing its participation as an electron sink from $18 \%$ in Equation 1 to $27 \%$ in Equation 3; similar shifts in the acetate to propionate ratio as a consequence of methanogenesis inhibition were reported by Ungerfeld et al. $(2003,2006)$ in vitro and Mitsumori et al. (2012) in vivo. Participation of $\mathrm{CH}_{4}$ as electron sink decreased from 73 to $6 \%$, and the remaining 33\% electron-pairs accumulated as $\mathrm{H}_{2}$ (calculations not shown). If the amount of hexose fermented does not change, $\mathrm{C}$ in the extra microbial biomass would come partly from less $\mathrm{C}$ in fermentation products (Dijkstra et al., 2007). The $\mathrm{C}$ shift from fermentation products to microbial biomass was not considered in Equation 3 in order to maintain the $\mathrm{C}$ balance explicit between fermented hexose and VFA and gases.

It is important to consider that, although the stoichiometric changes chosen are arbitrary, they do not affect the energetic and nutritional comparison that will be conducted between reductive acetogenesis and additional propionate as potential electron sinks for the accumulated $\mathrm{H}_{2}$. This is because, for any fermentation stoichiometry alternative to Equation 3 that could be chosen, the simulation that will be conducted would still compare the outcome of incorporating the same amount of accumulated $\mathrm{H}_{2}$ into either reductive acetogenesis or additional propionate formation.

\section{Reductive acetogenesis}

Reductive acetogenesis involves the reduction of $\mathrm{CO}_{2}$ by $\mathrm{H}_{2}$ to acetate:

$$
2 \mathrm{CO}_{2}+4 \mathrm{H}_{2} \longrightarrow \mathrm{CH}_{3} \mathrm{COO}^{-}+\mathrm{H}^{+}+2 \mathrm{H}_{2} \mathrm{O}
$$

Multiples of Equation 3 and 4 can be added up to result in different proportions of the accumulated $\mathrm{H}_{2}$ of Equation 3 being converted to acetate through reductive acetogenesis. Because $\mathrm{H}_{2}$ in Equation 3 is limiting in its ratio to $\mathrm{CO}_{2}$ in relation to the $\mathrm{H}_{2}$ to $\mathrm{CO}_{2}$ stoichiometry in Equation 4, reductive acetogenesis could, in theory, incorporate $100 \%$ of the accumulated $\mathrm{H}_{2}$ in Equation 3:

$$
\begin{aligned}
\mathrm{C}_{6} \mathrm{H}_{12} \mathrm{O}_{6}+9 / 59 \mathrm{H}_{2} \mathrm{O}+66 \mathrm{X} / 59 \longrightarrow 416 / 295 \mathrm{CH}_{3} \mathrm{COO}^{-} \\
+28 / 59 \mathrm{CH}_{3} \mathrm{CH}_{2} \mathrm{COO}^{-}+10 / 59 \mathrm{CH}_{3} \mathrm{CH}_{2} \mathrm{CH}_{2} \mathrm{COO}^{-} \\
+606 / 295 \mathrm{H}^{+}+603 / 590 \mathrm{CO}_{2}+33 / 590 \mathrm{CH}_{4} \\
+66 \mathrm{X}[2 \mathrm{H}] / 59
\end{aligned}
$$

Total incorporation of $\mathrm{H}_{2}$ is a theoretical limit; even in the typical ruminal fermentation with functional methanogenesis, $\mathrm{H}_{2}$ concentration varies between 0.1 and $50 \mu \mathrm{M}$ (Janssen, 2010). Generalizing Equation 5, incorporation of a positive fraction of accumulated $\mathrm{H}_{2}$ smaller or equal than unity into reductive acetogenesis is equal to:

$$
\begin{aligned}
& \mathrm{C}_{6} \mathrm{H}_{12} \mathrm{O}_{6}+(177-132 y) / 295 \mathrm{H}_{2} \mathrm{O}+66 \mathrm{X} / 59 \longrightarrow \\
&(350+66 y) / 295 \mathrm{CH}_{3} \mathrm{COO}^{-}+28 / 59 \mathrm{CH}_{3} \mathrm{CH}_{2} \mathrm{COO}^{-} \\
&+10 / 59 \mathrm{CH}_{3} \mathrm{CH}_{2} \mathrm{CH}_{2} \mathrm{COO}^{-}+(540+66 y) / 295 \mathrm{H}^{+} \\
&+(867-264 y) / 590 \mathrm{CO}_{2}+264(1-y) / 295 \mathrm{H}_{2} \\
&+33 / 590 \mathrm{CH}_{4}+66 \mathrm{X}[2 \mathrm{H}] / 59
\end{aligned}
$$

where $y$ is the proportion of accumulated $\mathrm{H}_{2}$ incorporated into reductive acetogenesis, $0 \leq y \leq 1$.

\section{Propionate formation}

Some propionate producers utilize $\mathrm{H}_{2}$ for reducing fumarate to succinate (Figure 1; Henderson, 1980). In agreement, an increase in $\mathrm{H}_{2}$ concentration thermodynamically stimulates propionate production (Janssen, 2010). Thus, accumulated $\mathrm{H}_{2}$ could, theoretically, be also utilized toward the formation of more propionate beyond the acetate to propionate shift typically associated to the inhibition of ruminal methanogenesis (i.e., further than the acetate to propionate shift of Equation 3 with respect to Equation 1). If the amount of fermented hexoses remains constant, $\mathrm{C}$ utilized to produce additional propionate would represent $\mathrm{C}$ in fermented hexoses not metabolized to other VFA or not used in anabolism. In the present analysis, it will be assumed that each extra mol of propionate is formed at the expense of $1 \mathrm{~mol}$ of acetate that is not produced, i.e., an acetate to propionate fermentation shift beyond that one typically observed associated with methanogenesis inhibition. For each mol of acetate that is not produced, 2 mol of reducing equivalents-pairs are not released:

$$
\begin{aligned}
& \mathrm{C}_{6} \mathrm{H}_{12} \mathrm{O}_{6}+2 \mathrm{H}_{2} \mathrm{O} \longrightarrow 2 \mathrm{CH}_{3} \mathrm{COO}^{-}+2 \mathrm{H}^{+} \\
& +2 \mathrm{CO}_{2}+4 \times[2 \mathrm{H}]
\end{aligned}
$$

Then, propionate formation competes for $\mathrm{C}$ with its major source of reducing equivalents, acetate formation. The acetate to propionate fermentation shift that redirects $\mathrm{C}$ and $\mathrm{H}_{2}$ toward propionate production is depicted in Equation 8:

$$
\mathrm{CH}_{3} \mathrm{COO}^{-}+\mathrm{CO}_{2}+3 \mathrm{H}_{2} \longrightarrow \mathrm{CH}_{3} \mathrm{CH}_{2} \mathrm{COO}^{-}+2 \mathrm{H}_{2} \mathrm{O}
$$

Incorporation of $100 \%$ of accumulated $\mathrm{H}_{2}$ in Equation 3 into propionate formation would result in:

$$
\begin{aligned}
\mathrm{C}_{6} \mathrm{H}_{12} \mathrm{O}_{6}+1 / 295 \mathrm{H}_{2} \mathrm{O}+66 \mathrm{X} / 59 \longrightarrow 262 / 295 \mathrm{CH}_{3} \mathrm{COO}^{-} \\
+228 / 295 \mathrm{CH}_{3} \mathrm{CH}_{2} \mathrm{COO}^{-}+10 / 59 \mathrm{CH}_{3} \mathrm{CH}_{2} \mathrm{CH}_{2} \mathrm{COO}^{-} \\
+108 / 59 \mathrm{H}^{+}+691 / 590 \mathrm{CO}_{2}+33 / 590 \mathrm{CH}_{4} \\
+66 \mathrm{X}[2 \mathrm{H}] / 59
\end{aligned}
$$

Equation 9 generalizes for any positive fraction of accumulated $\mathrm{H}_{2}$ smaller or equal than unity incorporated into extra 
propionate $(z)$ as:

$$
\begin{aligned}
& \mathrm{C}_{6} \mathrm{H}_{12} \mathrm{O}_{6}+(177-176 z) / 295 \mathrm{H}_{2} \mathrm{O}+66 \mathrm{X} / 59 \longrightarrow \\
& \quad(350-88 z) / 295 \mathrm{CH}_{3} \mathrm{COO}^{-}+(140+88 z) / 295 \mathrm{CH}_{3} \mathrm{CH}_{2} \mathrm{COO}^{-} \\
& +10 / 59 \mathrm{CH}_{3} \mathrm{CH}_{2} \mathrm{CH}_{2} \mathrm{COO}^{-}+108 / 59 \mathrm{H}^{+}+(867-176 z) / 590 \mathrm{CO}_{2} \\
& +264(1-z) / 295 \mathrm{H}_{2}+33 / 590 \mathrm{CH}_{4}+66 \mathrm{X}[2 \mathrm{H}] / 59
\end{aligned}
$$

where $0 \leq z \leq 1$

\section{SIMULATED FERMENTATION}

Stoichiometric responses in production of VFA and gases per mole of hexose fermented to $\mathrm{H}_{2}$ incorporation into reductive acetogenesis or additional propionate, were calculated as $y$ or $z$ in Equation 6 and 10, respectively, varied between 0 and 1 . The kinetics of reductive acetogenesis or additional propionate production, if they were thermodynamically feasible, could vary under different conditions. This analysis does not specify an incubation timeframe (if a batch culture system) or a fermentation rate (if a continuous culture system). Also, it was assumed that incorporation of electrons into other processes remained constant as accumulated $\mathrm{H}_{2}$ was incorporated into reductive acetogenesis or propionate formation. Results with total incorporation of accumulated $\mathrm{H}_{2}$ into reductive acetogenesis or additional propionate production (i.e., Equation 5 and 9, respectively) were also compared to the corresponding roughage fermentation with $\mathrm{CH}_{4}$ as main electron sink and no $\mathrm{H}_{2}$ accumulation (Equation 1).

\section{RESULTS}

As expected, the acetate to propionate ratio varied in opposite directions as accumulated $\mathrm{H}_{2}$ was incorporated into either reductive acetogenesis or additional propionate production, reaching 2.97 and 1.15 for total accumulated $\mathrm{H}_{2}$ incorporation into reductive acetogenesis and additional propionate production, respectively, (Figure 3). Hydrogen incorporation into reductive acetogenesis increased total VFA production, whereas $\mathrm{H}_{2}$ incorporation into additional propionate production did not change total VFA production because each additional mol of propionate was formed at the expense of one mol of acetate not produced (Figure 4).

Heat (or enthalpy) of combustion is equal to the total energy released as heat by complete oxidation of a compound to $\mathrm{CO}_{2}$ and $\mathrm{H}_{2} \mathrm{O}$ at constant pressure. Whereas heat of combustion in gaseous fermentation products like $\mathrm{CH}_{4}$ and $\mathrm{H}_{2}$ is lost to the atmosphere, VFA are absorbed through the rumen wall and are the main energy source for ruminants. Heat of combustion in VFA is then accounted as metabolizable energy (ME), as gaseous DE (DE in this analysis corresponds to energy in hexoses available for fermentation) losses have been discounted. Volatile fatty acids heats of combustion obtained from Kohn and Boston (2000) were used to calculate how heat of combustion output in VFA per mol of hexose fermented could vary whether accumulated $\mathrm{H}_{2}$ was incorporated into reductive acetogenesis or additional propionate (Figure 5). The responses in heat of combustion in VFA were virtually identical for $\mathrm{H}_{2}$ incorporation into reductive acetogenesis or additional propionate formation. Total $\mathrm{H}_{2}$ incorporation into either process resulted in a $12 \%$ gain in heat of combustion output

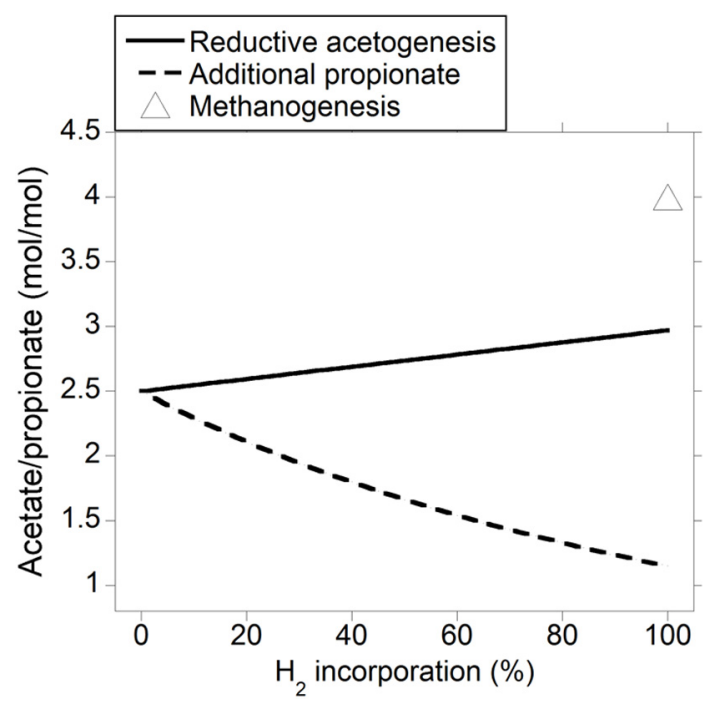

FIGURE 3 | Response of the acetate to propionate molar ratio to $\mathrm{H}_{2}$ incorporation into reductive acetogenesis or additional propionate formation. Corresponding fermentation with $\mathrm{CH}_{4}$ as main electron sink is provided as reference.

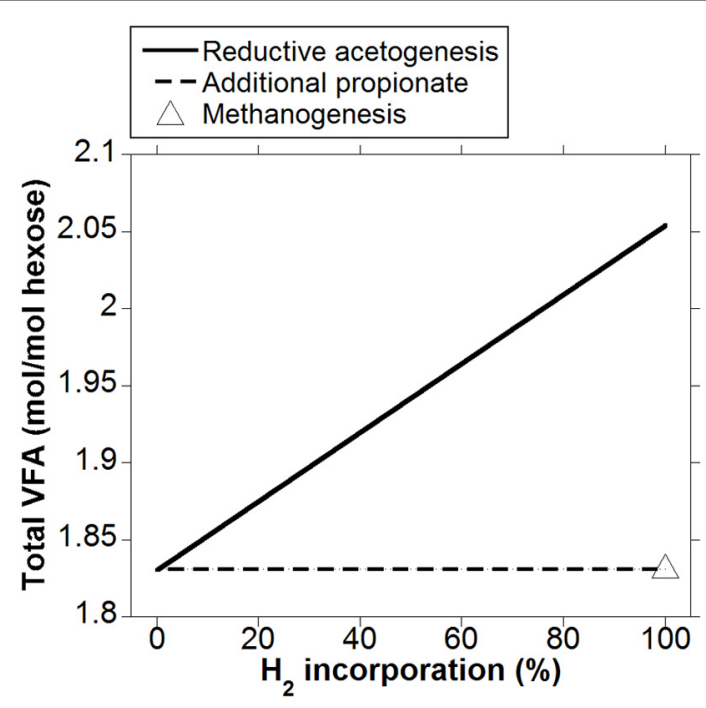

FIGURE 4 | Response of total VFA production to $\mathrm{H}_{2}$ incorporation into reductive acetogenesis or additional propionate formation.

Corresponding fermentation with $\mathrm{CH}_{4}$ as main electron sink is provided as reference.

in VFA compared to the corresponding fermentation with $\mathrm{CH}_{4}$ as main electron sink.

Even though incorporation of accumulated $\mathrm{H}_{2}$ into both reductive acetogenesis and additional propionate formation resulted in less $\mathrm{CO}_{2}$ released per mole of fermented hexose (not shown) due to $\mathrm{CO}_{2}$ incorporation into acetate or propionate, respectively, $\mathrm{CO}_{2}$ molar fraction in total gas produced actually increased (not shown). This is because the number of moles of $\mathrm{H}_{2}$ incorporated into either pathway was proportionally greater 


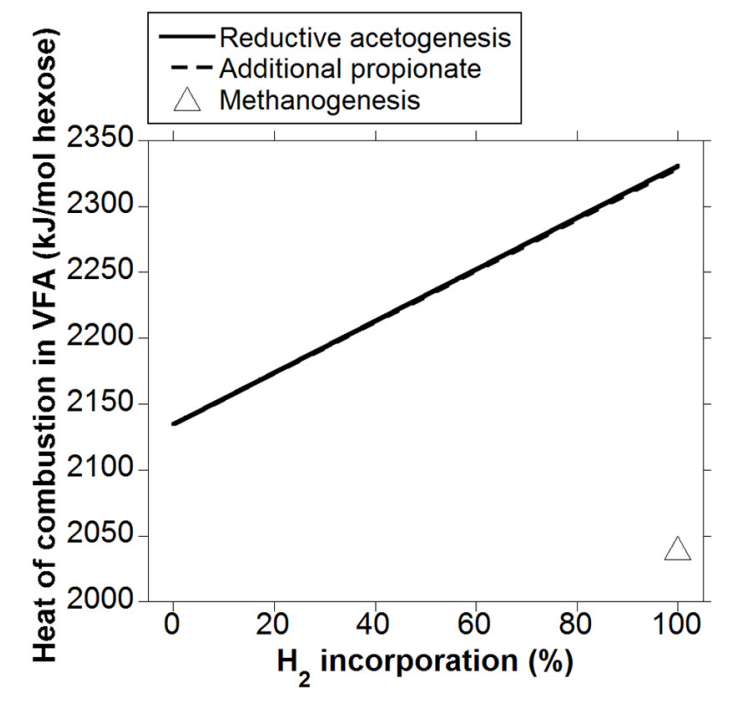

FIGURE 5 | Response in heat of combustion in VFA to $\mathrm{H}_{2}$ incorporation into reductive acetogenesis or additional propionate formation.

Corresponding fermentation with $\mathrm{CH}_{4}$ as main electron sink is provided as reference. than the incorporation of $\mathrm{CO}_{2}$ [the ratio between $\mathrm{H}_{2}$ and $\mathrm{CO}_{2}$ incorporated was of 2 to 1 for reductive acetogenesis (Equation 4) and of 3 to 1 for additional propionate formation (Equation 8)], and the small amount of $\mathrm{CH}_{4}$ remained constant. The implication is that, if total gas pressure remained constant (i.e., $\sim 10^{5}$ $\mathrm{Pa}), \mathrm{CO}_{2}$ pressure would actually increase as $\mathrm{H}_{2}$ was incorporated into reductive acetogenesis or additional propionate formation, because greater number of $\mathrm{H}_{2}$ moles relative to $\mathrm{CO}_{2}$ would be incorporated into either pathway (not shown).

Gibbs energy change (or Gibbs free energy change; $\Delta G$ ) of a chemical reaction is the theoretical limit to the amount of work that can be extracted from that reaction at constant pressure and temperature; because this limit would theoretically only be reached in a completely reversible reaction, it is never reached in a real non-equilibrium system. Reactions with negative $\Delta \mathrm{G}$ (exergonic) occur spontaneously provided their activation energy is overcome (catalysts decrease the activation energy of the reaction, allowing it to proceed faster). Reactions with positive $\Delta \mathrm{G}$ (endergonic) are non-spontaneous i.e., they are thermodynamically unfeasible unless coupled to a reaction with negative $\Delta G$ larger in absolute value. Reactions with $\Delta \mathrm{G}$ equal to zero are at equilibrium and their forward rate is equal to their reverse rate. Gibbs energy change was calculated both for incorporation of accumulated $\mathrm{H}_{2}$ into reductive acetogenesis or propionate production (Figure 6), and for the complete fermentation of glucose to VFA and gases for both electron-incorporating processes (Figure 7), as $\mathrm{H}_{2}$ incorporation varied between 0 and $100 \%$, assuming a total gas pressure of $10^{5} \mathrm{~Pa}$. Standard $\Delta \mathrm{G}$ of formation of metabolites in Equation 1, 6 and 10 were obtained from Kohn and Boston (2000) and Karadagli and Rittman (2007). Gibbs energy changes were adjusted to a ruminal temperature of $39^{\circ} \mathrm{C}$ through the Van't Hoff equation (Kohn and Boston, 2000). Partial pressure for each gas was calculated from the Ideal Gas Law, and

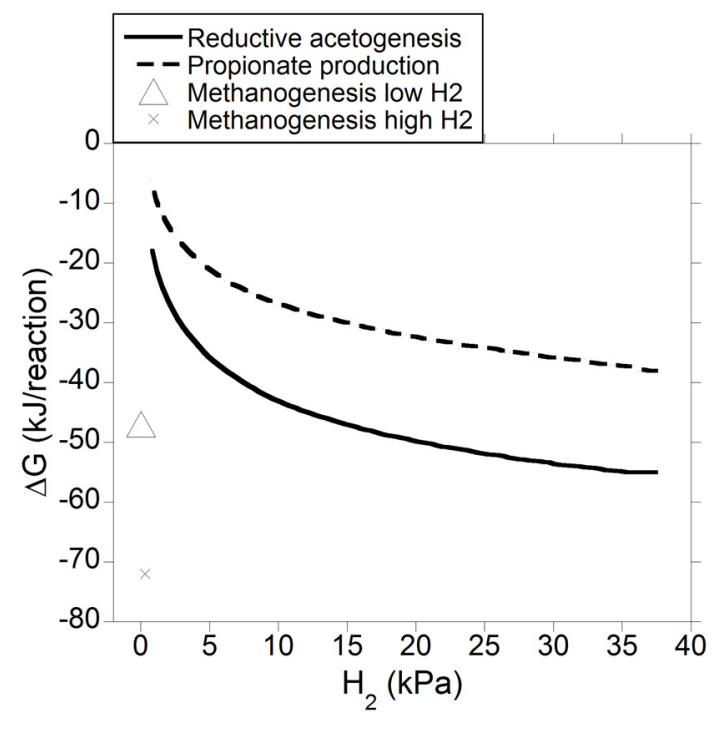

FIGURE 6 | Estimated $\Delta \mathbf{G}$ for reductive acetogenesis or additional propionate formation as a function of $\mathbf{H}_{\mathbf{2}}$ incorporation. Corresponding fermentation with $\mathrm{CH}_{4}$ as main electron sink is provided as reference.

dissolved gases concentrations were calculated from Henry's Law (Kohn and Boston, 2000; Janssen, 2010). Glucose concentration was assumed to be $6 \times 10^{-4} \mathrm{M}$ (Janssen, 2010). Water concentration was assumed to be $50 \mathrm{M}$ (Kohn and Boston, 2000). It is acknowledged that the upper limit of $\mathrm{H}_{2}$ pressure in Figure 6 is high for most methanogenesis-inhibition experiments, but similar values have been reported in some in vitro batch culture (Van Nevel et al., 1969; O'Brien et al., 2013) and in vivo (Rufener and Wolin, 1968; Trei et al., 1971, 1972; Kung et al., 2003) experiments where methanogenesis was inhibited.

Figure 6 depicts the thermodynamic feasibility of further incorporation of accumulated $\mathrm{H}_{2}$ into reductive acetogenesis (Equation 4) or propionate formation from acetate, $\mathrm{CO}_{2}$ and $\mathrm{H}_{2}$ (Equation 8) with varying $\mathrm{H}_{2}$ pressure resulting from different percentages of accumulated $\mathrm{H}_{2}$ incorporation into either pathway. Gibbs energy change of methanogenesis corresponding to a low and a high $\mathrm{H}_{2}$ concentration of 0.2 and $2.3 \mu \mathrm{M}$, respectively, is shown as reference (low and high $\mathrm{H}_{2}$ concentration values for high forage diets were obtained from Janssen, 2010, and converted to pressure using Henry's Law). As $\mathrm{H}_{2}$ pressure approached typical ruminal levels, both reductive acetogenesis and conversion of acetate to propionate rapidly approached equilibrium, as described by Ungerfeld and Kohn (2006), whereas, expectedly, methanogenesis was still thermodynamically favorable (Kohn and Boston, 2000).

Figure 7 shows how the entire fermentation $\Delta \mathrm{G}$ responded to varying $\mathrm{H}_{2}$ pressure resulting from accumulated $\mathrm{H}_{2}$ incorporation into reductive acetogenesis (Equation 6) or additional propionate formation (Equation 10), along with the corresponding roughage fermentation with $\mathrm{CH}_{4}$ as main electron sink (Equation 1). Estimated $\Delta G$ was comparable for both fermentation processes and varied little as accumulated $\mathrm{H}_{2}$ was incorporated into either reductive acetogenesis or additional propionate formation. 


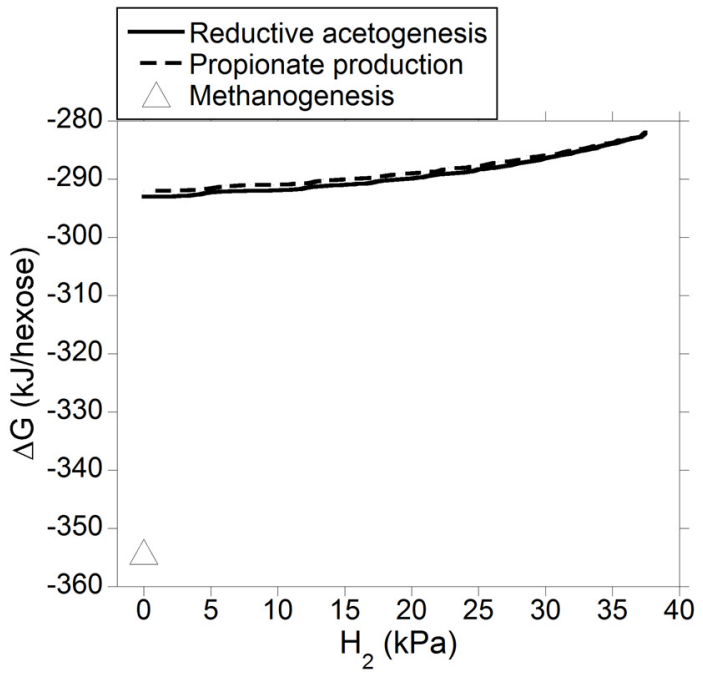

FIGURE 7 | Estimated $\Delta \mathrm{G}$ of fermentation with $\mathrm{H}_{2}$ incorporation into reductive acetogenesis or additional propionate formation as a function of $\mathbf{H}_{2}$ incorporation. Corresponding fermentation with $\mathrm{CH}_{4}$ as main electron sink is provided as reference.

Fermentation with $\mathrm{CH}_{4}$ as main electron sink was more favorable than theoretical $100 \%$ incorporation of accumulated $\mathrm{H}_{2}$ into either reductive acetogenesis or additional propionate formation.

\section{DISCUSSION}

Consequences of incorporation of accumulated $\mathrm{H}_{2}$ resulting from methanogenesis inhibition into reductive acetogenesis or additional propionate will be discussed with respect to four aspects of ruminant nutrition interest: fermentation energetics, microbial protein production, ruminal $\mathrm{pH}$, and VFA post-absorptive metabolism.

\section{FERMENTATION ENERGETICS}

The energetic equivalence of incorporating accumulated $\mathrm{H}_{2}$ into reductive acetogenesis or additional propionate is a result of the stoichiometries of both processes and of acetate and propionate heats of combustion. Reduction of $2 \mathrm{~mol}$ of $\mathrm{CO}_{2}$ with $4 \mathrm{~mol}$ of $\mathrm{H}_{2}$ to produce $1 \mathrm{~mol}$ of acetate results in a gain in heat of combustion in acetate per electron-pair incorporated equal to $876 \mathrm{~kJ} / 4$ $\mathrm{mol} \mathrm{H}_{2}=219 \mathrm{~kJ} / \mathrm{mol} \mathrm{H}_{2}$. Incorporation of $3 \mathrm{~mol}$ of $\mathrm{H}_{2}$ to produce $1 \mathrm{~mol}$ of propionate at the expense of $1 \mathrm{~mol}$ of acetate not being produced (Equation 9) results in a gain in heat of combustion in propionate per electron-pair incorporated equal to: $(1529-876 \mathrm{~kJ}) / 3 \mathrm{~mol} \mathrm{H}_{2}=218 \mathrm{~kJ} / \mathrm{mol} \mathrm{H}_{2}$. Ultimately, this result is predicted by the balance of the different types of chemical bonds broken and made (calculations not shown); even though incorporating accumulated $\mathrm{H}_{2}$ into reductive acetogenesis would result in greater total $\mathrm{C}$ retention in VFA compared to propionate production (not shown), a mole of propionate contains twice as many $\mathrm{C}$ atoms moles susceptible to be oxidized (i.e., methyl and methylene groups) than a mole of acetate, and total methyl plus methylene groups formed would be actually slightly greater if accumulated $\mathrm{H}_{2}$ was incorporated into propionate (Figure 8).

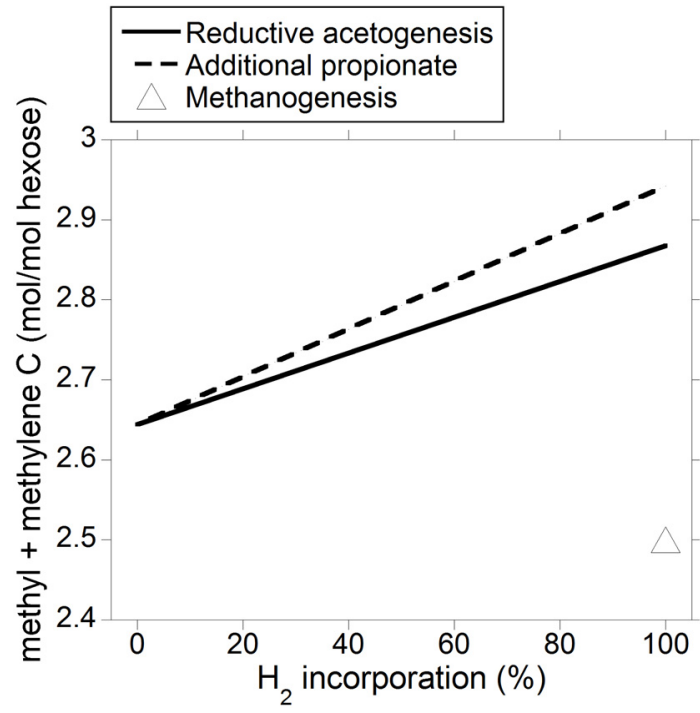

FIGURE 8 | Response in total VFA methyl plus methylene groups output to $\mathrm{H}_{2}$ incorporation into reductive acetogenesis or additional propionate formation. Corresponding fermentation with $\mathrm{CH}_{4}$ as main electron sink is provided as reference.

Incorporation of $\mathrm{H}_{2}$ into either reductive acetogenesis or propionate production resulted in an increase in heat of combustion in VFA of about $12 \%$ with respect to the corresponding fermentation with $\mathrm{CH}_{4}$ as main electron sink. As discussed, this energy gain corresponds to ME. Given that a range of 2 to $12 \%$ gross energy is lost as $\mathrm{CH}_{4}$ (Attwood and McSweeney, 2008), the corresponding range for a roughage diet of, for example, $60 \%$ energy metabolisability, would be 3 to $20 \%$. Therefore, the proportion of ME lost as $\mathrm{CH}_{4}$ agrees with previous sources (Attwood and McSweeney, 2008).

Apart from what could be the energetic consequence of incorporating accumulated $\mathrm{H}_{2}$ into reductive acetogenesis or propionogenesis, a very important question is, of course, why neither process is the main electron sink in ruminal fermentation, and methanogenesis is instead the dominant electron sink.. It has been shown that reductive acetogenesis is negligible in ruminal incubations (Nollet et al., 1997a; Le Van et al., 1998), and attempts to induce it by adding reductive acetogens have been unsuccessful (López et al., 1999). Reductive acetogens have been isolated from the rumen (Leedle and Greening, 1988) and identified using molecular techniques (Henderson et al., 2010), but they seem to rely on mixotrophic growth i.e., substrates other than $\mathrm{CO}_{2}$ and $\mathrm{H}_{2}$, and to use diverse electron acceptors (Joblin, 1999; Drake et al., 2002).

As a redox process, methanogenesis has a lower $\mathrm{H}_{2}$ threshold than reductive acetogenesis (Cord-Ruwisch et al., 1988), which allows methanogens to lower $\mathrm{H}_{2}$ partial pressure at a level at which reductive acetogenesis is thermodynamically unfeasible; reductive acetogenesis has been estimated to be close to equilibrium at ruminal conditions even without considering ATP generation (Kohn and Boston, 2000). Thus, adding reductive acetogens to rumen fermentation only enhances reductive acetogenesis enzyme kinetics, whereas the process is thermodynamically 
limited and therefore methanogenesis remains dominating. Two different low $\mathrm{H}_{2}$-threshold acetogens decreased methanogenesis between 64 and 97\% when co-cultured with Methanobrevibacter sp. (Joblin, 1999); however, these co-cultures were grown under elevated $\mathrm{H}_{2}$ pressure, which would remove methanogenesis thermodynamic advantage, as opposed to ruminal conditions, where $\mathrm{H}_{2}$ originates only from fermentation. This experiment though would demonstrate a kinetic advantage in terms of $V_{\max }$ for utilizing $\mathrm{H}_{2}$ of these acetogens over their Methanobrevibacter competitor when reductive acetogenesis thermodynamic disadvantage was overcome. It is suggested to repeat this kind of experiments both in the presence of external $\mathrm{H}_{2}$ and as tricultures with $\mathrm{H}_{2}$-producing organisms. Similarly, the presence of a live yeast enhanced the competitive capacity of a reductive acetogen against a methanogen (Chaucheyras et al., 1995), but this again happened when the thermodynamic constraint to reductive acetogenesis was removed by growing the tri-culture under artificially elevated $\mathrm{H}_{2}$ pressure.

Whereas it does not occur in the rumen, reductive acetogenesis co-exists with or even dominates over methanogenesis in other gut environments: wood-digesting termites, rodents, pigs, humans (Joblin, 1999), young rabbits (Piattoni et al., 1996), marsupials (Ouwerkerk et al., 2009), ostriches (Fievez et al., 2001), newborn lambs (Morvan et al., 1994) and ruminant hindguts (Immig, 1996), contributing to the host animal energetic requirements. Addition of the reductive acetogen Peptostreptococcus productus ATCC 35244 to an in vitro reactor simulating the human gut inoculated with human faces resulted in a decrease in methanogenesis to a level below detection limit (Nollet et al., 1997b), but did not affect methanogenesis in ruminal incubations (Nollet et al., 1997a). It is therefore important to understand the reasons for why reductive acetogenesis occurs in those environments and does not occur in the rumen.

Despite methanogenesis being thermodynamically more favorable than reductive acetogenesis, conditions like low $\mathrm{pH}$ or low temperature can diminish methanogenesis and make reductive acetogenesis more competitive in certain freshwater lake sediments, flooded rice paddies or tundra wetland soils (Drake et al., 2002). Transiently elevated $\mathrm{H}_{2}$ concentration in marine sediments resulting from a low sulphate concentration period allowed reductive acetogenesis to become thermodynamically feasible (Hoehler et al., 1999). In the wood-feeding termite Reticulitermes flavipes hindgut, reductive acetogens occupy the more reduced lumen with high $\mathrm{H}_{2}$ pressure, and methanogens are displaced to the micro-oxic periphery (Ebert and Brune, 1997). Association of reductive acetogens to $\mathrm{H}_{2}$-producing protozoa in the termite gut also seems to contribute to favoring reductive acetogenesis over methanogenesis in that environment (Leadbetter et al., 1999). In agreement, reductive acetogenesis seems to be an important hydrogen sink in the ruminant hindgut, where protozoa are absent (Immig, 1996). However, an explanation is yet missing for why spatial differences that may allow reductive acetogenesis becoming thermodynamically feasible in wood-feeding termite hindguts do not occur in the rumen i.e., why ruminal reductive acetogens do not displace methanogens from the more reducing microniches and why they do not associate with protozoa. Perhaps, rates of $\mathrm{H}_{2}$ production in environments like the wood-feeding termites hindgut lumen are greater than in the rumen and remove thermodynamic constraints to reductive acetogenesis. Under those conditions reductive acetogenesis could become dominant if reductive acetogens had a greater capacity to utilize $\mathrm{H}_{2}$ at high concentration (i.e., higher $V_{\max }$ ) than methanogens; then, as $\mathrm{H}_{2}$ availability decreases toward the termite hindgut periphery, reductive acetogenesis would become thermodynamically unfeasible and methanogenesis would become the $\mathrm{H}_{2}$ sink close to the hindgut epithelium. It is also possible that at low $\mathrm{H}_{2}$ pressure methanogens rely on a lower $K_{\mathrm{m}}$ for $\mathrm{H}_{2}$ to establish in the termite gut periphery. Although I am not aware of measured kinetic parameters of methanogens and reductive acetogens competing for $\mathrm{H}_{2}$ in the same environment, it has been proposed that microbial specialists (methanogens in this case) have greater affinities for the substrates they compete for than their generalist competitors (Lever, 2012).

As opposed to reductive acetogenesis, propionate production is already an electron sink in ruminal fermentation, but second to methanogenesis with regard to its quantitative importance. As it has been shown, $\mathrm{CH}_{4}$ production and the VFA profile are intimately related. From a purely stoichiometric point of view, propionate could, theoretically, replace $\mathrm{CH}_{4}$ as an electron sink. For example:

$$
\begin{aligned}
\mathrm{C}_{6} \mathrm{H}_{12} \mathrm{O}_{6} \longrightarrow 2 / 3 \mathrm{CH}_{3} \mathrm{COO}^{-}+ & 4 / 3 \mathrm{CH}_{3} \mathrm{CH}_{2} \mathrm{COO}^{-}+2 \mathrm{H}^{+} \\
& +2 / 3 \mathrm{CO}_{2}+2 / 3 \mathrm{H}_{2} \mathrm{O}
\end{aligned}
$$

It is clear, however, that the stoichiometry proposed in Equation 11 is well outside what is observed for ruminal fermentation. The question that then arises is: is the competition between methanogenesis and propionate production for metabolic hydrogen in the rumen controlled by thermodynamics or by affinity for $\mathrm{H}_{2}$ ? Co-culturing of succinate and propionate producers with methanogens resulted in a decrease in succinate or propionate production (Chen and Wolin, 1977; Latham and Wolin, 1977; Marvin-Sikkema et al., 1990). In my opinion, those shifts in fermentation in co-cultures cannot not be explained by affinity for $\mathrm{H}_{2}$, because $\mathrm{H}_{2}$ transferred to methanogens needs to be first produced by hydrogenases in the fermentative organism; any competition for $\mathrm{H}_{2}$ must have been preceded by an intracellular shift in the flux of metabolic hydrogen driven either by thermodynamics or by kinetic competition between hydrogenases and fumarate or acrylyl-CoA reductases for NADH.

Of course, the above results with co-cultures apply to organisms possessing the metabolic capacity to produce propionate or succinate, but not necessarily to the competition for $\mathrm{H}_{2}$ produced by the mixed microbiota that does not have this capacity. At least some propionate producers are able to use $\mathrm{H}_{2}$ to reduce fumarate to succinate (Henderson, 1980), which is manifested by the shift from acetate to propionate production occurring with an increase in $\mathrm{H}_{2}$ pressure (Janssen, 2010). How is then the competition between methanogens and propionate producers for the extracellular $\mathrm{H}_{2}$ pool controlled? It has been shown that methanogens have a lower $K_{\mathrm{m}}$ for $\mathrm{H}_{2}$ than fumarate reducers (Russell and Wallace, 1997; Asanuma et al., 1999). On the other hand, an analysis derived from published values concluded that opposite 
interconversion flows between VFA (i.e., Equation 8) are generally similar, which was interpreted as an indication that VFA are close to equilibrium much of the time, and that the range of VFA ratios commonly observed for ruminal fermentation, and hence $\mathrm{CH}_{4}$ production, could be the result of thermodynamic control (Ungerfeld and Kohn, 2006).

Another important problem is that, as discussed, even in the methanogenesis-inhibited ruminal fermentation, neither reductive acetogenesis nor propionate production, incorporate the totality of reducing equivalents from inhibited $\mathrm{CH}_{4}$, as manifested by the fact that $\mathrm{H}_{2}$ accumulates. The question, therefore, is why $\mathrm{H}_{2}$ accumulates instead of being incorporated into reductive acetogenesis or propionate production or both. Organisms conducting the pathways depicted en Equation 4 and 8 would need to utilize some of the negative $\Delta \mathrm{G}$ associated to those reactions to generate ATP to make their own endergonic anabolic reactions thermodynamically feasible to grow fast enough so as to not get washed out of the rumen. Gibbs energy change of ATP hydrolysis to ADP and phosphate is about $-50 \mathrm{~kJ} / \mathrm{mol}$ (Voet and Voet, 1995). Then, the $\Delta G$ needed for the reverse reaction, the generation of $1 \mathrm{~mol}$ of ATP, appears to be similar to the $\Delta \mathrm{G}$ of reductive acetogenesis (Equation 4) and propionate production from acetate, $\mathrm{CO}_{2}$ and $\mathrm{H}_{2}$ (Equation 8$)$ at $37 \mathrm{kPa} \mathrm{H} \mathrm{H}_{2}(0 \%$ incorporation of accumulated $\mathrm{H}_{2}$; Figure 6). This may therefore be taken as an indication that $\mathrm{H}_{2}$ accumulation in the methanogenesisinhibited rumen results from the system reaching thermodynamic equilibrium regarding further incorporation of $\mathrm{H}_{2}$ reducing equivalents into reductive acetogenesis or propionate production. However, this interpretation would conflict with the decrease in $\mathrm{H}_{2}$ pressure observed upon addition of reductive acetogens to methanogenesis-inhibited batch cultures (Nollet et al., 1997a; Le Van et al., 1998; López et al., 1999). Yet, organisms growing in batch cultures do not get washed out, and perhaps they could survive generating less than 1 ATP mol through ion gradient-driven phosphorylation per mol of acetate (Equation 4) or propionate (Equation 8) produced. Also, the discrepancy between the thermodynamic calculation for reductive acetogenesis in Figure 6 and the experimental in vitro results (Nollet et al., 1997a; Le Van et al., 1998; López et al., 1999) could be explained by $\mathrm{H}_{2}$ oversaturation in the liquid phase, where it is generated, with respect to the gas phase, which would result in $\mathrm{H}_{2}$-utilizing reactions being more favorable for microbes than what calculations assuming $\mathrm{H}_{2}$ saturation would suggest (Hackmann, 2013). Furthermore, $\mathrm{H}_{2}$ gradients exist in anaerobic environments (Boone et al., 1989), and are likely to exist between liquid and particle ruminal compartments (Czerkawski, 1986), making some reactions more favorable at particular locations. An example of a ruminal $\mathrm{H}_{2}$ gradient is the physical association of some methanogens with protozoa to be closer to a $\mathrm{H}_{2}$ source (Morgavi et al., 2010).

Through adding propionate formation intermediates, Tatsuoka et al. (2008) and Ebrahimi et al. (2011) had some success at decreasing $\mathrm{H}_{2}$ accumulation in methanogenesis-inhibited ruminal batch incubations, which would indicate, that at least under their conditions, propionate formation was limited by thermodynamics or substrate kinetics (through the availability of a C skeleton). Fonty et al. (2007) found that addition of fumarate to a methanogen-free ruminal incubation accelerated
$\mathrm{H}_{2}$ utilization without affecting its final point at $24 \mathrm{~h}$, which would suggest a limitation of a substrate kinetic nature.

\section{MICROBIAL PROTEIN PRODUCTION}

With most ruminant diets, microbial protein is the principal source of amino acids for the host animal (Bach et al., 2005). It is also the cheapest one, as ruminants can use $\mathrm{N}$ sources with no nutritional value to non-ruminants (Wallace et al., 1997). Microbial protein synthesis can be understood as the product between the number of moles of ATP generated in fermentation and the amount of protein synthesized per mole of ATP hydrolyzed.

Generation of ATP is made possible by negative $\Delta \mathrm{G}$ of fermentation reactions. Fermentation $\Delta \mathrm{G}$ for incorporation of accumulated $\mathrm{H}_{2}$ into reductive acetogenesis or additional propionate formation was estimated to be similar (Figure 7). However, only part of fermentation $\Delta \mathrm{G}$ in Figure 7 is available to generate ATP; if all of $\Delta G$ associated to fermentation was coupled to an endergonic process like ATP generation, fermentation would be at equilibrium and come to a halt. It is difficult to compare Equation 6 and 10 with regard to ATP generation. Generation of ATP associated to ion-gradient-driven phosphorylation occurs both in reductive acetogenesis (Müller, 2003), the propionate randomizing pathway (Russell and Wallace, 1997), and methanogenesis (Thauer et al., 2008), and the stoichiometry of ATP generation per pair of electrons may not be constant (Reddy and Peck, 1978; Kröger and Winkler, 1981; Thauer et al., 2008). In addition, ATP generation in propionate production would vary depending on the mechanism of oxaloacetate formation and the ratio of C flow through the randomizing (via oxaloacetate and succinate) vs. non-randomizing (via lactate) pathway (Russell and Wallace, 1997). Thus, the proportion of fermentation $\Delta \mathrm{G}$ in Figure 7 actually utilized by cells to generate ATP is unknown and could vary depending on the organism and conditions.

The typical roughage fermentation with $\mathrm{CH}_{4}$ as main electron sink depicted in Equation 1 appeared to be more exergonic than either Equation 6 or Equation 10 at any point of $\mathrm{H}_{2}$ accumulation (Figure 7), and, perhaps could conserve greater $\Delta \mathrm{G}$ per mol of glucose fermented. On the other hand, methanogenesis inhibition in vitro has resulted in an increase in microbial N production (Ungerfeld et al., 2007; Guo et al., 2009), possibly due to greater availability of reducing equivalents for anabolic reactions (Czerkawski, 1986). Thus, even if methanogenesis inhibition resulted in a less exergonic fermentation, production of microbial $\mathrm{N}$ protein might still be favored because synthetic reactions could become energetically less costly (Czerkawski, 1986). More experimentation is needed to understand the effects of methanogenesis inhibition on microbial growth, and alternative explanations to stimulation of anabolic reactions have been proposed. Ungerfeld et al. (2007) also speculated that the methanogenesis inhibitor propynoic acid might have improved microbial growth and efficiency through protozoal inhibition, although protozoa were not quantified in that study. Lila et al. (2004) and Mohammed et al. (2004) did not find changes in protozoal numbers as a consequence of inhibiting $\mathrm{CH}_{4}$ production in ruminal batch incubations. Microbial biomass production was not measured in those studies. 
The second factor determining the microbial protein production is the amount of protein synthesized per mole of ATP hydrolyzed. Anabolic efficiency is influenced by factors such as the presence of glucose phosphotransferase transport systems, disaccharides phosphorylases, energy conservation through transmembrane electrochemical gradients, variation in cell composition, variation in maintenance energy, and energy-spilling reactions (Russell and Wallace, 1997). It is unknown how mixed microbial populations conducting the pathways depicted in Equation 6 and 10 could compare with regards to those factors. Because they use the reductive acetylCoA pathway for both $\mathrm{C}$ fixation and catabolism, it has been speculated that reductive acetogens might be able to survive and replicate maintaining smaller genomes and fewer enzymes, which could decrease their energy requirements (Lever, 2012). Experimentation would be needed to understand how incorporation of accumulated $\mathrm{H}_{2}$ into reductive acetogenesis or propionate production can affect microbial protein production.

\section{RUMINAL pH}

Incorporation of accumulated $\mathrm{H}_{2}$ into reductive acetogenesis would result in increased total VFA production, whereas additional propionate formation would not affect it (Figure 4). The relationship between VFA concentration and $\mathrm{pH}$ was weak across studies with different diets (Allen, 1997), but for this analysis a common basal diet is assumed, and possible changes in ruminal $\mathrm{pH}$ are discussed as the sole consequence of $\mathrm{H}_{2}$ incorporation into reductive acetogenesis or propionate production. Changes in VFA concentration need not reflect changes in VFA production proportionally, as VFA absorption also increases (Penner et al., 2009b, 2011); therefore, the calculation that follows represents an upper limit to $\mathrm{pH}$ decrease as a consequence of greater VFA production.

Assuming a hypothetical but realistic total VFA concentration of $100 \mathrm{mM}$ for maximum $\mathrm{H}_{2}$ accumulation (Equation 3), total incorporation of accumulated $\mathrm{H}_{2}$ into reductive acetogenesis (Equation 5) could result in a total VFA concentration of
$112 \mathrm{mM}$ due to maximal additional $12 \mathrm{mM}$ acetate (calculation from Figure 4), if greater VFA production was not compensated to any extent by greater absorption. Buffering capacity (BC) of a solution is the molar $\mathrm{H}^{+}$concentration required to cause a change in $\mathrm{pH}$, at a certain $\mathrm{pH}: \mathrm{BC}=d \mathrm{H}^{+} / d \mathrm{pH}$ (Counotte et al., 1979). Ruminal fluid BC reported in various studies is summarized in Table 1. Then, the expected decrease in $\mathrm{pH}$ for the maximum extra $12 \mathrm{mM} \mathrm{H}^{+}$due to an additional $12 \mathrm{mM}$ acetate concentration would be equal to $-0.012 \mathrm{M} /$ BC.

In addition, if total gas pressure remained at 1 atm after total incorporation of accumulated $\mathrm{H}_{2}$ into reductive acetogenesis or additional propionate, $\mathrm{CO}_{2}$ pressure would increase from approximately 0.60 to 0.95 atm (calculations not shown). Based on Kohn and Dunlap (1998), it can be derived (not shown) that if bicarbonate concentration remained constant, $\mathrm{pH}$ would change by:

$$
\Delta \mathrm{pH}=\log (0.60 \mathrm{~atm} / 0.95 \mathrm{~atm})=-0.20
$$

The expected decrease in $\mathrm{pH}$ for $\mathrm{H}_{2}$ incorporation into reductive acetogenesis calculated from BC, adjusted for Equation 12, is shown in Table 1. In most cases, there was a moderate $\mathrm{pH}$ decrease. It should be considered that changes in VFA production could affect other physiological mechanisms such as buffer secretion due to bicarbonate secreted by rumen epithelium in exchange for absorbed VFA anions, most importantly acetate (Penner et al., 2009a; Aschenbach et al., 2011). Therefore, effects of $\mathrm{H}_{2}$ incorporation into reductive acetogenesis or additional propionate on ruminal $\mathrm{pH}$ are difficult to predict accurately, and in vivo experimentation would be needed to completely understand how ruminal $\mathrm{pH}$ could be affected.

\section{VOLATILE FATTY ACIDS POST-ABSORPTIVE METABOLISM Efficiency of VFA utilization}

Utilization by the animal of heat of combustion in VFA is incomplete, as heat is lost in the conversion of ME to net

Table 1 | Ruminal fluid buffering capacity determinations and estimated maximal $\mathrm{pH}$ decrease for $\mathrm{H}_{2}$ incorporation into reductive acetogenesis.

\begin{tabular}{|c|c|c|c|}
\hline Reference & $\begin{array}{l}\mathrm{BC} \text { (average and range, } \mathrm{M} \\
\mathrm{H}^{+} / \mathrm{pH} \text { unit) }\end{array}$ & $\begin{array}{l}\mathrm{pH} \text { of } \mathrm{BC} \\
\text { determination }\end{array}$ & $\begin{array}{l}\text { Calculated pH } \\
\text { decrease }\end{array}$ \\
\hline Turner and Hodgetts (1955)a & $0.028(0.013-0.042)$ & $5.80-6.90$ & 0.63 \\
\hline Counotte et al. (1979) ${ }^{\mathrm{b}}$ & $0.038(0.021-0.063)$ & $6.2^{c}$ & 0.52 \\
\hline Murphy et al. (1983)d & $0.013(0.009-0.02)$ & $7^{e}$ & 1.12 \\
\hline
\end{tabular}

${ }^{a}$ Determined under a $\mathrm{CO}_{2}$ and $\mathrm{N}_{2}$ mixture (proportions not reported).

${ }^{b}$ Determined under $\mathrm{CO}_{2}$.

${ }^{c}$ Ruminal fluid $\mathrm{pH}$ was 6.09-7.20.

${ }^{d}$ Determined under a 50:50 $\mathrm{CO}_{2}: \mathrm{N}_{2}$ mixture and a $5 \mathrm{~mm}$ layer of mineral oil.

${ }^{e}$ Ruminal fluid $\mathrm{pH}$ was 5.80-6.14.

${ }^{f}$ Ruminal fluid $\mathrm{pH}$ was 5.77-5.81.

${ }^{g}$ Ruminal fluid $\mathrm{pH}$ was 6.49-6.8. 
energy (NE) for maintenance or production (heat increment, $\mathrm{HI})$. Initial experiments with intra-ruminally-infused VFA in fasting (Armstrong and Blaxter, 1957a; Armstrong et al., 1957) and fattening sheep (Armstrong and Blaxter, 1957b) resulted in greater HI for pure acetate compared to pure propionate. Mixtures of VFA were similar to pure propionate in fasting animals (Armstrong and Blaxter, 1957a; Armstrong et al., 1957), but a VFA mixture high in acetate was associated to a greater HI compared to one high in propionate when administered to sheep fed above maintenance (Armstrong et al., 1958). Later work found similar HI for VFA mixtures varying in acetate and propionate proportions in lactating cows (Ørskov et al., 1969), fasting and fattening lambs (Ørskov et al., 1979), and steers at different feeding levels, except for a decreased $\mathrm{HI}$ at the highest acetate molar proportion due to acetate excretion in urine (Ørskov et al., 1991; Ørskov and MacLeod, 1993).

Therefore, it seems that the differences in VFA profiles resulting from the incorporation of accumulated $\mathrm{H}_{2}$ into reductive acetogenesis or additional propionate formation may not affect the efficiency of absorbed VFA utilization in animals at maintenance, thus likely resulting in similar NE outputs, given that heat of combustion output in VFA was similar (Figure 5); this issue would be unresolved for producing animals.

\section{Post-absorptive metabolic effects of VFA}

Apart from being energy sources, absorbed acetate and propionate have different metabolic consequences for ruminant post-absorptive metabolism (DiConstanzo et al., 1999). As a general frame of analysis, one could conceive the extra acetate or propionate formed through incorporation of accumulated $\mathrm{H}_{2}$ as an intervention analogous to adding a ketogenic or glycogenic supplement, respectively, to a basal diet. Although dietary effects on energy partition and milk production and composition are primarily explained by duodenal flow of conjugated linoleic acid isomers, they also partly respond to changes in production of acetate and propionate in the rumen (Maxin et al., 2011). It should be cautioned though that changes in $\mathrm{pH}$ and individual VFA ruminal concentrations could affect individual VFA absorption fluxes differently: absorption flux of propionate, but not of acetate, increased as a result of greater inclusion of dietary concentrates and corresponding greater propionate molar proportion and lower $\mathrm{pH}$; the effect of diet on each VFA absorption flux seemed to follow changes in their concentrations, as rumen volume and fractional absorption rates of individual VFA were unaffected (Penner et al., 2009b).

Propionate is the main glucose precursor in ruminants, so it may be advantageous to produce more propionate in animals with high glucose requirements e.g., high-producing dairy cows (Aschenbach et al., 2010). However, dairy cows fed a ketogenic diet partitioned more energy to milk compared to those fed a glycogenic diet equal in NE (Van Knegsel et al., $2007 a, b, c)$, which agrees with changes in energy excretion in milk observed as a response to intra-ruminal infusion of acetate or propionate (Ørskov et al., 1969) and intramesenteric infusion of propionate (Casse et al., 1994). Ketogenic diets generally resulted in greater milk fat content and production, whereas both were lesser with glycogenic diets (Van Knegsel et al., 2005, $2007 a, b)$. In agreement, intra-ruminal infusion of acetate resulted in greater milk fat content and production compared to propionate infusion (Ørskov et al., 1969; Sheperd and Combs, 1998; Maxin et al., 2011). On the contrary, glycogenic diets often increased, and ketogenic diets decreased, milk protein content (Van Knegsel et al., 2005, 2007a,b). Propionate infusion resulted in greater milk protein content (Sheperd and Combs, 1998).

However, ketogenic diets are associated to greater negative energy balance and risk of ketosis (Van Knegsel et al., 2005, 2007a,c). Importantly, there can be an interaction between the basal diet and the supplement regarding the risk of ketosis. Supplementing a ketogenic basal diet with fat resulted in an increase in circulating concentration of $B$ hydroxybutyrate, in contrast to a glycogenic basal diet (Van Knegsel et al., 2005). Thus, consequences of incorporating accumulated $\mathrm{H}_{2}$ into reductive acetogenesis or additional propionate on the risk of ketosis may be more important with forage-based and fat-supplemented diets than with mixed diets.

Van Knegsel et al. (2005) did a thorough analysis of studies on the effects of ketogenic or glycogenic supplementation on reproduction and found it difficult to conclude on consistent effects. However, direct comparisons between ketogenic and glycogenic diets suggested that the latter may be advantageous for reproduction (Van Knegsel et al., 2007a,c).

In animals with a production potential not limited by glucose supply, or with no risk of ketosis, there may be no a clear advantage of reductive acetogenesis or propionate formation as electron-incorporating pathway. Moreover, propionate is a major satiety signal in ruminants (Allen et al., 2009); thus, it may be preferable to incorporate accumulated $\mathrm{H}_{2}$ into reductive acetogenesis in animals whose basal diet already satisfies their glucose requirements, if their dry matter intake (DMI) is metabolically constrained, e.g., steers on high-concentrate diets. However, in feedlot steers with subclinical acidosis, incorporating $\mathrm{H}_{2}$ into reductive acetogenesis could result in further $\mathrm{pH}$ decrease, which could in turn diminish DMI. There may not be advantages to reductive acetogenesis vs. additional propionate formation as an electron-incorporating pathway in animals with low glucose requirements if feed intake is not to be maximized e.g., beef cows.

\section{FUTURE DIRECTIONS}

Evidently the conclusions reached through the present analysis would have to be tested through experimentation. Experimentally comparing effects of redirecting methanogenesis electrons toward reductive acetogenesis or propionate production on animal physiology and production is at present difficult, because attempts to inhibit methanogenesis have had little success in incorporating electrons into one or the other pathway. In my opinion, a question that precedes the question on how to incorporate methanogenesis electrons into reductive acetogenesis or propionate production, is, what limits those processes in the rumen i.e., how is $\mathrm{H}_{2}$ incorporation into reductive acetogenesis and 
propionate production physico-chemically controlled. Physicochemical control of $\mathrm{H}_{2}$ incorporation into reductive acetogenesis or propionate production could be based primarily on enzyme or substrate kinetics, or thermodynamics. It is important to understand this in order to efficiently design strategies that can achieve successful incorporation of methanogenesis electrons into these pathways.

For example, an enzyme kinetics limitation could be solved through microbial intervention e.g., microbial additives, overexpression of particular genes etc. On the other hand, a limitation of a substrate kinetics or thermodynamics nature would require an intervention at the level of substrate availability and/or product removal, and might be less feasible or profitable in practice.

It would be best to test these hypotheses in very simplified systems, like chemostats running on soluble substrates where steady state constant kinetics and thermodynamic conditions can be attained. Defined cultures experiments on interspecies $\mathrm{H}_{2}$ transfer similar to the ones conducted some decades ago but including measurements of changes in the expression of genes encoding key enzymes such as hydrogenases and fumarate and acrylyl-CoA reductases, as well as the activities of those enzymes, are also suggested. Once this basic understanding was achieved, experimentation could move toward more realistic in vitro systems using solid substrates, and finally in vivo conditions. The underlying principle beyond this proposal is that a system can be better manipulated if we can understand how the flow of metabolites is controlled. Mechanistic understanding of ruminal fermentation will provide a long term solid basis to develop efficient strategies of manipulation of rumen fermentation and better predict and understand the outcomes of new strategies.

In summary, incorporating accumulated $\mathrm{H}_{2}$ into reductive acetogenesis or additional propionate formation was found to be equivalent in terms of ME, and of NE for animals at maintenance; whether the efficiency of conversion of ME to NE in producing animals could be different if $\mathrm{H}_{2}$ was incorporated into reductive acetogenesis or additional propionate formation would remain unresolved. Incorporation of accumulated $\mathrm{H}_{2}$ into reductive acetogenesis could result in moderate ruminal $\mathrm{pH}$ decrease, although in vivo experimentation would be needed to characterize complex whole animal responses, as whole-animal responses other than ruminal fermentation could be affected. Research would be needed on the consequences of $\mathrm{H}_{2}$ incorporation into either pathway on microbial protein production. Post-absorptive consequences of either pathway on energy partition into milk and body tissues, risk of ketosis in dairy cows, and DMI could differ. Utilization of reductive acetogenesis as the preferred electron-incorporating pathway could stimulate energy partition into milk over body fat, although in high-producing dairy cows eating ketogenic diets could result in greater risk of ketosis. Incorporating accumulated $\mathrm{H}_{2}$ into propionate could increase milk protein and could decrease the risk of ketosis in animals eating ketogenic diets. However, in animals with metabolically constrained DMI and sufficient propionate or glucose supply, like steers on high-concentrate diets, incorporation of accumulated $\mathrm{H}_{2}$ into propionate could result in decreased DMI; in steers with subclinical acidosis though, reductive acetogenesis may cause further $\mathrm{pH}$ decline.

Results of this comparison can be used to guide future research efforts in this area. This analysis shows that the production outcome of a successful ruminal methanogenesis intervention could depend on the alternative electron-incorporating pathway. Because of the different nutritional implications of either pathway, and because practical solutions to incorporate accumulated $\mathrm{H}_{2}$ into either pathway are not yet available, it is recommended to continue exploring both reductive acetogenesis and additional propionate production as electron sinks alternative to methanogenesis.

\section{ACKNOWLEDGMENTS}

I wish to thank the reviewers for their constructive comments that helped improving this publication.

\section{REFERENCES}

Allen, M. S. (1997). Relationship between fermentation acid production in the rumen and the requirement for physically effective fiber. J. Dairy Sci. 80, 1447-1462. doi: 10.3168/jds.S0022-0302(97)76074-0

Allen, M. S., Bradford, B. J., and Oba, M. (2009). Board invited review: the hepatic oxidation theory of the control of feed intake and its application to ruminants. J. Anim. Sci. 87, 3317-3334. doi: 10.2527/jas.2009-1779

Armstrong, D. G., and Blaxter, K. L. (1957a). The heat increment of steamvolatile fatty acids in fasting sheep. Br. J. Nutr. 2, 247-273. doi: 10.1079/ BJN19570044

Armstrong, D. G., and Blaxter, K. L. (1957b). The utilization of acetic, propionic and butyric acids by fattening sheep. Br. J. Nutr. 2, 413-425. doi: 10.1079/BJN19570063

Armstrong, D. G., Blaxter, K. L., and Graham, N. M.cC. (1957). The heat increment of mixtures of steam-volatile fatty acids in fasting sheep. Br. J. Nutr. 2, 392-408. doi: 10.1079/BJN19570061

Armstrong, D. G., Blaxter, K. L., Graham, N. M.cC., and Wainman, F. W. (1958). The utilization of the energy of two mixtures of steam-volatile fatty acids by fattening sheep. Br. J. Nutr. 12, 177-188. doi: 10.1079/BJN19580025

Asanuma, N., Iwamoto, M., and Hino, T. (1999). Effect of the addition of fumarate on methane production by ruminal microorganisms in vitro. J. Dairy Sci. 82, 780-787. doi: 10.3168/jds.S0022-0302(99)75296-3

Aschenbach, J. R., Kristensen, N. B., Donkin, S. S., Hammon, H. M., and Penner, G. B. (2010). Gluconeogenesis in dairy cows: the secret of making sweet milk from sour dough. IUBMB Life 62, 869-877. doi: 10.1002/iub.400

Aschenbach, J. R., Penner, G. B., Stumpff, F., and Gäbel, G. (2011). Ruminant nutrition symposium: role of fermentation acid absorption in the regulation of ruminal pH. J. Anim. Sci. 89, 1092-1107. doi: 10.2527/jas. 2010-3301

Attwood, G., and McSweeney, C. (2008). Methanogen genomics to discover targets for methane mitigation technologies and options for alternative $\mathrm{H}_{2}$ utilisation in the rumen. Austr. J. Exp. Agr. 48, 28-37. doi: 10.1071/EA07203

Bach, A., Calsamiglia, S., and Stern, M. D. (2005). Nitrogen metabolism in the rumen. J. Dairy Sci. 88 (Suppl. 1), E9-E21. doi: 10.3168/jds.S00220302(05)73133-7

Bannink, A., France, J., Lopez, S., Gerrits, W. J. J., Kebreab, E., Tamminga, S., et al. (2008). Modelling the implications of feeding strategy on rumen fermentation and functioning of the rumen wall. Anim. Feed Sci. Tech. 143, 3-26. doi: 10.1016/j.anifeedsci.2007.05.002

Bannink, A., Kogut, J., Dijkstra, J., France, J., Kebreab, E., and Van Vuuren, A. M. (2006). Estimation of the stoichiometry of volatile fatty acid production in the rumen of lactating cows. J. Theor. Biol. 238, 36-51. doi: 10.1016/j.jtbi.2005.05.026

Boone, D. R., Johnson, R. L., and Liu, Y. (1989). Diffusion of the interspecies electron carriers $\mathrm{H}_{2}$ and formate in methanogenic ecosystems and its implications in the measurement of $\mathrm{Km}$ for $\mathrm{H}_{2}$ or formate uptake. Appl. Environ. Microbiol. 55, 1735-1741. 
Casse, E. A., Rulquin, H., and Huntington, G. B. (1994). Effect of mesenteric vein infusion of propionate on splanchnic metabolism in primiparous Holstein cows. J. Dairy Sci. 77, 3296-3303. doi: 10.3168/jds.S0022-0302(94)77270-2

Chaucheyras, F., Fonty, G., Bertin, G., and Gouet, P. (1995). In vitro $\mathrm{H}_{2}$ utilization by a ruminal acetogenic bacterium cultivated alone or in association with an Archaea methanogen is stimulated by a probiotic strain of Saccharomyces cerevisiae. Appl. Environ. Microbiol. 61, 3466-3467.

Chen, M., and Wolin, M. J. (1977). Influence of $\mathrm{CH}_{4}$ production by Methanobacterium ruminantium on the fermentation of glucose and lactate by Selenomonas ruminantium. Appl. Environ. Microbiol. 34, 756-759.

Cord-Ruwisch, R., Seitz, H.-J., and Conrad, R. (1988). The capacity of hydrogenotrophic anaerobic bacteria to compete for traces of hydrogen depends on the redox potential of the terminal electron acceptor. Arch. Microbiol. 149, 350-357. doi: 10.1007/BF00411655

Counotte, G. H. M., Van't Klooster, A. T., Van der Kuilen, J., and Prins, R. A. (1979). An analysis of the buffer system in the rumen of dairy cattle. J. Anim. Sci. 49, 1536-1544.

Czerkawski, J. W. (1986). An Introduction to Rumen Studies. Exeter: Pergamon Press.

DiConstanzo, A., Williams, J. E., and Keisler, D. H. (1999). Effect of short- or longterm infusions of acetate or propionate on lutenizing hormone, insulin, and metabolite concentrations in beef heifers. J. Anim. Sci. 77, 3050-3056.

Dijkstra, J., Kebreab, E., Mills, J. A. N., Pellikaan, W. F., López, S., Bannink, A., et al. (2007). Predicting the profile of nutrients available for absorption: from nutrient requirement to animal response and environmental impact. Animal 1, 99-111. doi: 10.1017/S1751731107657760

Drake, H. L., Küsel, K., and Matthies, C. (2002). Ecological consequences of the phylogenetic and physiological diversities of acetogens. Antonie van Leeuwenhoek 81, 203-213. doi: 10.1023/A:1020514617738

Ebert, A., and Brune, A. (1997). Hydrogen concentration profiles at the oxicanoxic interface: a microsensor study of the hindgut of the wood-feeding lower termite Reticulitermes flavipes (Kollar). Appl. Environ. Microbiol. 63, 4039-4046.

Ebrahimi, S. H., Mohini, M., Singhal, K. K., Miri, V. H., and Tyagi, A. K. (2011). Evaluation of complementary effects of 9, 10-anthraquinone and fumaric acid on methanogenesis and ruminal fermentation in vitro. Arch. Anim. Nutr. 65, 267-277. doi: 10.1080/1745039X.2011.594345

Fievez, V., Mbanzamihigo, L., Piattoni, F., and Demeyer, D. (2001). Evidence for reductive acetogenesis and its nutritional significance in ostrich hindgut as estimated from in vitro incubations. J. Anim. Physiol. Anim. Nutr. 85, 271-280. doi: 10.1046/j.1439-0396.2001.00320.x

Fonty, G., Joblin, K., Chavarot, M., Roux, R., Naylor, G., and Michallon, F. (2007). Establishment and development of ruminal hydrogenotrophs in methanogenfree lambs. Appl. Environ. Microbiol. 73, 6391-6403. doi: 10.1128/AEM.0018107

Froetschel, M. A., and Amos, H. E. (1991). Effects of dietary fiber and feeding frequency on ruminal fermentation, digesta water-holding capacity, and fractional turnover of contents. J. Anim. Sci. 69, 1312-1321.

Goel, G., Makkar, H. P. S., and Becker, K. (2009). Inhibition of methanogens by bromochloromethane: effects on microbial communities and rumen fermentation using batch and continuous fermentations. Br. J. Nutr. 101, 1484-1492. doi: 10.1017/S0007114508076198

Guo, W. S., Schaefer, D. M., Guo, X. X., Ren, L. P., and Meng, Q. X. (2009). Use of nitrate-nitrogen as sole dietary nitrogen source to inhibit ruminal methanogenesis and to improve microbial nitrogen synthesis in vitro. Asian Aust. J. Anim. Sci. 22, 542-549. doi: 10.1007/s00253-013-5143-z

Hackmann, T. J. (2013). Responses of Rumen Microbes to Excess Carbohydrate. Ph.D. Dissertation, The Ohio State University, Columbus, OH.

Henderson, C. (1980). The influence of extracellular hydrogen on the metabolism of Bacteroides ruminicola, Anaerovibrio lipolytica and Selenomonas ruminantium. J. Gen. Microbiol. 119, 485-491.

Henderson, G., Naylor, G. E., Leahy, S. C., and Janssen, P. H. (2010). Presence of novel, potentially homoacetogenic bacteria in the rumen as determined by analysis of formyltetrahydrofolate synthetase sequences from ruminants. Appl. Environ. Microbiol. 76, 2058-2066. doi: 10.1128/ AEM.02580-09

Hodgson, J. C., and Thomas, P. C. (1975). A relationship between the molar proportion of propionic acid and the clearance rate of the liquid phase in the rumen of sheep. Br. J. Nutr. 33, 447-456. doi: 10.1079/ BJN19750048
Hoehler, T. M., Albert, D. B., Alperin, M. J., and Martens, C. S. (1999). Acetogenesis from $\mathrm{CO}_{2}$ in an anoxic marine sediment. Limnol. Oceanogr. 44, 662-667. doi: 10.4319/lo.1999.44.3.0662

Hungate, R. E., Mah, R. A., and Simesen, M. (1961). Rates of production of individual volatile fatty acids in the rumen of lactating cows. Appl. Microbiol. 9, $554-561$.

Immig, I. (1996). The rumen and hindgut as source of ruminant methanogenesis. Environ. Monitor. Assess. 42, 57-72. doi: 10.1007/BF00394042

Janssen, P. H. (2010). Influence of hydrogen on rumen methane formation and fermentation balances through microbial growth kinetics and fermentation thermodynamics. Anim. Feed Sci. Tech. 160, 1-22. doi: 10.1016/j.anifeedsci.2010.07.002

Joblin, K. N. (1999). Ruminal acetogens and their potential to lower ruminant methane emissions. Aust. J. Agric. Res. 50, 1307-1313. doi: 10.1071/AR99004

Karadagli, F., and Rittman, B. E. (2007). Thermodynamic and kinetic analysis of the $\mathrm{H}_{2}$ threshold of Methanobacterium bryantii M.o.H. Biodegradation 18, 439-452. doi: 10.1007/s10532-006-9073-7

Kohn, R. A., and Boston, R. C. (2000). "The Role of thermodynamics in controlling rumen metabolism," in Modelling Nutrient Utilization in Farm Animals, eds J. P. McNamara, J. France, and D. E. Beever (Oxon-New York: CAB International), 11-24. doi: 10.1079/9780851994499.0011

Kohn, R. A., and Dunlap, T. F. (1998). Calculation of the buffering capacity of bicarbonate in the rumen and in vitro. J. Anim. Sci. 76, 1702-1709.

Kröger, A., and Winkler, E. (1981). Phosphorylative fumarate reduction in Vibrio succinogenes: stoichiometry of ATP synthesis. Arch. Microbiol. 129, 100-104. doi: 10.1007/BF00417188

Kung, L. Jr., Smith, K. A., Smagala, A. M., Endres, K. M., Bessett, C. A., Ranjit, N. K., et al. (2003). Effects of 9, 10 anthraquinone on ruminal fermentation, totaltract digestion, and blood metabolite concentration in sheep. J. Anim. Sci. 81, 323-328.

Latham, M. J., and Wolin, M. J. (1977). Fermentation of cellulose by Ruminococcus flavefaciens in the presence and absence of Methanobacterium ruminantium. Appl. Environ. Microbiol. 34, 297-301.

Le Van, T. D., Robinson, J. A., Ralph, J., Greening, R. C., Smolenski, W. J., Leedle, J. A. Z., et al. (1998). Assessment of reductive acetogenesis with indigenous ruminal bacterium populations and Acetitomaculum ruminis. Appl. Environ. Microbiol. 64, 3429-3436.

Leadbetter, J. R., Schmidt, T. M., Graber, J. R., and Breznak, J. A. (1999). Acetogenesis from $\mathrm{H}_{2}$ plus $\mathrm{CO}_{2}$ by spirochetes from termite guts. Science 283, 686-689. doi: 10.1126/science.283.5402.686

Leedle, J. A. Z., and Greening, R. C. (1988). Postprandial changes in methanogenic and acidogenic bacteria in the rumens of steers fed high- or low-forage diets once daily. Appl. Environ. Microbiol. 54, 502-506.

Lever, M. A. (2012). Acetogenesis in the energy-starved deep biosphere-a paradox. Front. Microbiol. 2:284. doi: 10.3389/fmicb.2011.00284

Lila, Z. A., Mohammed, N., Tatsuoka (Ajisaka), N., Kanda, S., Kurokawa, Y., and Itabashi, H. (2004). Effect of cyclodextrin diallyl maleate on methane production, ruminal fermentation and microbes in vitro and in vivo. Anim. Sci. J. 75, 15-22. doi: 10.1111/j.1740-0929.2004.00149.x

López, S., McIntosh, F. M., Wallace, R. J., and Newbold, C. J. (1999). Effect of adding acetogenic bacteria on methane production by mixed rumen microorganisms. Anim. Feed Sci. Tech. 78, 1-9. doi: 10.1016/S0377-8401(98)00273-9

Marvin-Sikkema, F. D., Richardson, A. J., Stewart, C. S., Gottschal, J. C., and Prins, R. A. (1990). Influence of hydrogen-consuming bacteria on cellulose degradation by anaerobic fungi. Appl. Environ. Microbiol. 56, 3793-3797.

Maxin, G., Glasser, F., Hurtaud, C., Peyraud, J. L., and Rulquin, H. (2011). Combined effects of trans-10, cis-12 conjugated linoleic acid, propionate, and acetate on milk fat yield and composition in dairy cows. J. Dairy Sci. 94, 2051-2059. doi: 10.3168/jds.2010-3844

Mitsumori, M., Shinkai, T., Takenaka, A., Enishi, O., Higuchi, K., Kobayashi, Y., et al. (2012). Responses in digestion, rumen fermentation and microbial populations to inhibition of methane formation by a halogenated methane analogue. Br. J. Nutr. 108, 482-491. doi: 10.1017/S0007114511005794

Mohammed, N., Ajisaka, N., Lila, Z. A., Hara, K., Mikuni, K., Hara, K., et al. (2004). Effect of Japanese horseradish oil on methane production and ruminal fermentation in vitro and in steers. J. Anim. Sci. 82, 1839-1846.

Morgavi, D. P., Forano, E., Martin, C., and Newbold, C. J. (2010). Microbial ecosystem and methanogenesis in ruminants. Animal 4, 1024-1036. doi: $10.1017 /$ S1751731110000546 
Morvan, B., Dore, J., Rieu-Lesme, F., Foucat, L., Fonty, G., and Gouet, P. (1994). Establishment of hydrogen-utilizing bacteria in the rumen of the newborn lamb. FEMS Microbiol. Lett. 117, 249-256. doi: 10.1111/j.1574-6968.1994.tb06775.x

Müller, V. (2003). Energy conservation in acetogenic bacteria. Appl. Environ. Microbiol. 69, 6345-6353. doi: 10.1128/AEM.69.11.6345-6353.2003

Murphy, M. R., Whetstone, H. D., and Davis, C. L. (1983). Effect of source and particle size of supplemental phosphate on rumen function of steers fed high concentrate diets. J. Dairy Sci. 66, 2526-2532. doi: 10.3168/jds.S00220302(83)82122-5

Nollet, L., Demeyer, D., and Verstraete, W. (1997a). Effect of 2bromoethanesulfonic acid and Peptostreptococcus productus ATCC 35244 addition on stimulation of reductive acetogenesis in the ruminal ecosystem by selective inhibition of methanogenesis. Appl. Environ. Microbiol. 63, 194-200.

Nollet, L., Vande Velde, I., and Verstraete, W. (1997b). Effect of the addition of Peptostreptococcus productus ATCC35244 on the gastro-intestinal microbiota and its activity, as simulated in an in vitro simulator of the human gastro-intestinal tract. Appl. Microbiol. Biotechnol. 48, 99-104. doi: $10.1007 / \mathrm{s} 002530051022$

Nollet, L., Mbanzamihigo, L., Demeyer, D., and Verstraete, W. (1998). Effect of the addition of Peptostreptococcus productus ATCC 35244 on reductive acetogenesis in the ruminal ecosystem after inhibition of methanogenesis by cell-free supernatant of Lactobacillus plantarum 80. Anim. Feed Sci. Tech. 71, 49-66. doi: 10.1016/S0377-8401(97)00135-1

O’Brien, M., Navarro-Villa, A., Purcell, P. J., Boland, T. M., and O'Kiely, P. (2013). Reducing in vitro rumen methanogenesis for two contrasting diets using a series of inclusion rates of different additives. Anim. Prod. Sci. doi: 10.1071/AN12204. Available online at: http://www.publish.csiro.au/view/journals/dsp_journal_ fulltext.cfm?nid=72\&f=AN12204

Ørskov, E. R., Flatt, W. P., Moe, P. W., Munson, A. W., Hemken, R. W., and Katz, I. (1969). The influence of ruminal infusion of volatile fatty acids on milk yield and composition and on energy utilization by lactating cows. Br. J. Nutr. 23, 443-453. doi: 10.1079/BJN19690054

Ørskov, E. R., Grubb, D. A., Smith, J. S., Webster, A. J. F., and Corrigal, W. (1979). Efficiency of utilization of volatile fatty acids for maintenance and energy retention in sheep. Br. J. Nutr. 41, 541-551. doi: 10.1079/BJN19790069

Ørskov, E. R., and MacLeod, N. A. (1993). Effect of level of input of different proportions of volatile fatty acids on energy utilization in growing ruminants. $\mathrm{Br}$. J. Nutr. 70, 679-687. doi: 10.1079/BJN19930163

Ørskov, E. R., MacLeod, N. A., and Nakashima, Y. (1991). Effect of different volatile fatty acids mixtures on energy metabolism in cattle. J. Anim. Sci. 69, 3389-3397.

Ouwerkerk, D., Maguire, A. J., McMillen, L., and Klieve, A. V. (2009). Hydrogen utilising bacteria from the forestomach of eastern grey (Macropus giganteus) and red (Macropus rufus) kangaroos. Anim. Prod. Sci. 49, 1043-1051. doi: 10.1071/EA08294

Penner, G. B., Aschenbach, J. R., Gäbel, G., Rackwitz, R., and Oba, M. (2009a). Epithelial capacity for apical uptake of short chain fatty acids is a key determinant for intraruminal $\mathrm{pH}$ and the susceptibility to subacute ruminal acidosis in sheep. J. Nutr. 139, 1714-1720. doi: 10.3945/jn.109.108506

Penner, G. B., Taniguchi, M., Guan, L. L., Beauchemin, K. A., and Oba, M. (2009b). Effect of dietary forage to concentrate ratio on volatile fatty acid absorption and the expression of genes related to volatile fatty acid absorption and metabolism in ruminal tissue. J. Dairy Sci. 92, 2767-2781. doi: 10.3168/jds.2008-1716

Penner, G. B., Steele, M. A., Aschenbach, J. R., and McBride, B. W. (2011). Ruminant nutrition symposium: molecular adaptation of ruminal epithelia to highly fermentable diets. J. Anim.Sci. 89, 1108-1119. doi: 10.2527/jas.2010-3378

Piattoni, F., Demeyer, D. I., and Maertens, L. (1996). In vitro study of the agedependent caecal fermentation pattern and methanogenesis in young rabbits. Reprod. Nutr. Dev. 36, 253-261. doi: 10.1051/rnd:19960303

Reddy, C. A., and Peck, H. D. Jr. (1978). Electron transport phosphorylation coupled to fumarate reduction by $\mathrm{H}_{2}$ - and $\mathrm{Mg}^{2+}$-dependent adenosine triphosphatase activity in extracts of the rumen anaerobe Vibrio succinogenes. J. Bacteriol. 134, 982-991.

Rufener, W. H. Jr., and Wolin, M. J. (1968). Effect of $\mathrm{CCl}_{4}$ on $\mathrm{CH}_{4}$ and volatile acid production in continuous cultures of rumen organisms and in a sheep rumen. Appl. Microbiol. 16, 1955-1956.

Russell, J. B., and Wallace, R. J. (1997). "Energy-yielding and energy-consuming reactions," in The Rumen Microbial Ecosystem, eds P. N. Hobson and C. S. Stewart (London: Blackie Academic and Professional), 246-282. doi: 10.1007/978-94-009-1453-7_6
Sauer, F. D., and Teather, R. M. (1987). Changes in oxidation reduction potentials and volatile fatty acid production by rumen bacteria when methane synthesis is inhibited. J. Dairy Sci. 70, 1835-1840. doi: 10.3168/jds.S0022-0302(87)80222-9

Sheperd, A. C., and Combs, D. K. (1998). Long-term effects of acetate and propionate on voluntary feed intake by midlactation cows. J. Dairy Sci. 81, 2240-2250. doi: 10.3168/jds.S0022-0302(98)75803-5

Stanier, G., and Davies, A. (1981). Effects of the antibiotic monensin and an inhibitor of methanogenesis on in vitro continuous rumen fermentations. $\mathrm{Br}$. J. Nutr. 45, 567-578. doi: 10.1079/BJN19810135

Tatsuoka, N., Hara, K., Mikuni, K., Hara, K., Hashimoto, H., and Itabashi, H. (2008). Effects of the essential oil cyclodextrin complexes on ruminal methane production in vitro. Anim. Sci. J. 79, 68-75. doi: 10.1111/j.17400929.2007.00499.x

Thauer, R. K., Kaster, A. -K., Seedorf, H., Buckel, W., and Hedderich, R. (2008). Methanogenic archaea: ecologically relevant differences in energy conservation. Nat. Rev. Microbiol. 6, 579-591. doi: 10.1038/nrmicro1931

Tissera, G. H., Vandersall, J. H., and Erdman, R. A. (1988). Effects of limestone on starch digestion in Holstein steers. J. Dairy Sci. 71, 754-761. doi: 10.3168/jds.S0022-0302(88)79615-0

Tomkins, N. W., Colegate, S. M., and Hunter, R. A. (2009). A bromochloromethane formulation reduces enteric methanogenesis in cattle fed grain-based diets. Anim. Prod. Sci. 49, 1053-1058. doi: 10.1071/EA08223

Trei, J. E., Parish, R. C., Singh, Y. K., and Scott, G. C. (1971). Effect of methane inhibitors on rumen metabolism and feedlot performance of sheep. J. Dairy Sci. 54, 536-540. doi: 10.3168/jds.S0022-0302(71)85882-4

Trei, J. E., Scott, G. C., and Parish, R. C. (1972). Influence of methane inhibition on energetic efficiency of lambs. J. Anim. Sci. 34, 510-515.

Turner, A. W., and Hodgetts, V. E. (1955). Buffer systems in the rumen of sheep. II. Buffering properties in relationship to composition. Aust. J. Agric. Res. 6, 125-144. doi: 10.1071/AR9550125

Ungerfeld, E. M., and Kohn, R. A. (2006). "The role of thermodynamics in the control of ruminal fermentation," in Ruminant Physiology, eds K. Sejrsen, T. Hvelplund, and M. O. Nielsen (Wageningen: Wageningen Academic Publishers), 55-85.

Ungerfeld, E. M., Rust, S. R., and Burnett, R. (2003). Use of some novel alternative electron sinks to inhibit ruminal methanogenesis. Reprod. Nutr. Dev. 43, 189-202. doi: 10.1051/rnd:2003016

Ungerfeld, E. M., Rust, S. R., and Burnett, R. (2006). Effects of butyrate precursors on electron relocation when methanogenesis is inhibited in ruminal mixed cultures. Lett. Appl. Microbiol. 42, 567-572. doi: 10.1111/j.1472-765X.2006.01890.x

Ungerfeld, E. M., Rust, S. R., and Burnett, R. (2007). Increases in microbial nitrogen production and efficiency in vitro with three inhibitors of ruminal methanogenesis. Can. J. Microbiol. 53, 496-503. doi: 10.1139/W07-008

Van Knegsel, A. T. M., Van den Brand, H., Dijkstra, J., and Kemp, B. (2007a). Effect of dietary energy source on energy balance, metabolites and reproduction variables in dairy cows in early lactation. Theriogenology 68S, S274-S280. doi: 10.1016/j.theriogenology.2007.04.043

Van Knegsel, A. T. M., Van den Brand, H., Dijkstra, J., Van Straalen, W. M., Heetkamp, M. J. W., Tamminga, S., et al. (2007b). Dietary energy source in dairy cows in early lactation: energy partitioning and milk composition. J. Dairy Sci. 90, 1467-1476. doi: 10.3168/jds.S0022-0302(07)71632-6

Van Knegsel, A. T. M., Van den Brand, H., Dijkstra, J., Van Straalen, W. M., Jorritsma, R., Tamminga, S., et al. (2007c). Effect of glucogenic vs. lipogenic diets on energy balance, blood metabolites, and reproduction in primiparous and multiparous dairy cows in early lactation. J. Dairy Sci. 90, 3397-3409. doi: 10.3168/jds.2006-837

Van Knegsel, A. T. M., Van den Brand, H., Dijkstra, J., Tamminga, S., and Kemp, B. (2005). Effect of dietary energy source on energy balance, production, metabolic disorders and reproduction in lactating dairy cattle. Reprod. Nutr. Dev. 45, 665-688. doi: 10.1051/rnd:2005059

Van Nevel, C. J., Henderickx, H. K., Demeyer, D. I., and Martin, J. (1969). Effect of chloral hydrate on methane and propionic acid in the rumen. Appl. Microbiol. 17, 695-700.

Van Zijderveld, S. M., Gerrits, W. J. J., Apajalahti, J. A., Newbold, J. R., Dijkstra, J., Leng, R. A., et al. (2010). Nitrate and sulfate: effective alternative hydrogen sinks for mitigation of ruminal methane production in sheep. J. Dairy Sci. 93, 5856-5866. doi: 10.3168/jds.2010-3281

Voet, D., and Voet, J. G. (1995). Biochemistry. New York; Chichester; Brisbane; Toronto; Singapore: John Wiley and Sons, Inc. 
Wallace, R. J., Onodera, R., and Cotta, M. A. (1997). "Metabolism of nitrogencontaining compounds," in The Rumen Microbial Ecosystem, eds P. N. Hobson and C. S. Stewart (London: Blackie Academic and Professional), 283-328. doi: 10.1007/978-94-009-1453-7_7

Wolin, M. J., Miller, T. L., and Stewart, C. S. (1997). "Microbe-microbe interactions," in The Rumen Microbial Ecosystem, eds P. N. Hobson and C. S. Stewart (London: Blackie Academic and Professional), 467-491. doi: 10.1007/978-94009-1453-7_11

Conflict of Interest Statement: The author declares that the research was conducted in the absence of any commercial or financial relationships that could be construed as a potential conflict of interest.
Received: 05 August 2013; accepted: 10 October 2013; published online: 30 October 2013.

Citation: Ungerfeld EM (2013) A theoretical comparison between two ruminal electron sinks. Front. Microbiol. 4:319. doi: 10.3389/fmicb.2013.00319

This article was submitted to Systems Microbiology, a section of the journal Frontiers in Microbiology.

Copyright (C) 2013 Ungerfeld. This is an open-access article distributed under the terms of the Creative Commons Attribution License (CC BY). The use, distribution or reproduction in other forums is permitted, provided the original author(s) or licensor are credited and that the original publication in this journal is cited, in accordance with accepted academic practice. No use, distribution or reproduction is permitted which does not comply with these terms. 


\section{APPENDIX A}

Summary of equations with decimal coefficients

Equation 1: Example of typical fermentation of glucose with a high-roughage diet

$$
\begin{aligned}
& \mathrm{C}_{6} \mathrm{H}_{12} \mathrm{O}_{6} \longrightarrow 1.333 \mathrm{CH}_{3} \mathrm{COO}^{-}+0.333 \mathrm{CH}_{3} \mathrm{CH}_{2} \mathrm{COO}^{-} \\
& +0.167 \mathrm{CH}_{3} \mathrm{CH}_{2} \mathrm{CH}_{2} \mathrm{COO}^{-}+1.833 \mathrm{H}^{+}+\mathrm{CO}_{2} \\
& +0.667 \mathrm{CH}_{4}+0.333 \mathrm{H}_{2} \mathrm{O}
\end{aligned}
$$

Equation 2: Example of typical fermentation of glucose with a high-concentrate diet

$$
\begin{aligned}
& \mathrm{C}_{6} \mathrm{H}_{12} \mathrm{O}_{6} \longrightarrow 0.923 \mathrm{CH}_{3} \mathrm{COO}^{-}+0.615 \mathrm{CH}_{3} \mathrm{CH}_{2} \mathrm{COO}^{-} \\
& +0.231 \mathrm{CH}_{3} \mathrm{CH}_{2} \mathrm{CH}_{2} \mathrm{COO}^{-}+1.769 \mathrm{H}^{+}+0.962 \mathrm{CO}_{2} \\
& +0.423 \mathrm{CH}_{4}+0.538 \mathrm{H}_{2} \mathrm{O}
\end{aligned}
$$

Equation 3: Example of methanogenesis inhibition in highroughage diet of Equation 1

$$
\begin{aligned}
& \mathrm{C}_{6} \mathrm{H}_{12} \mathrm{O}_{6}+0.6 \mathrm{H}_{2} \mathrm{O}+1.119 \mathrm{X} \longrightarrow 1.186 \mathrm{CH}_{3} \mathrm{COO}^{-} \\
& +0.475 \mathrm{CH}_{3} \mathrm{CH}_{2} \mathrm{COO}^{-}+0.169 \mathrm{CH}_{3} \mathrm{CH}_{2} \mathrm{CH}_{2} \mathrm{COO}^{-} \\
& +1.831 \mathrm{H}^{+}+1.469 \mathrm{CO}_{2}+0.895 \mathrm{H}_{2}+0.0559 \mathrm{CH}_{4} \\
& +1.119 \mathrm{X}[2 \mathrm{H}]
\end{aligned}
$$

Equation 4: Reductive acetogenesis

$$
2 \mathrm{CO}_{2}+4 \mathrm{H}_{2} \longrightarrow \mathrm{CH}_{3} \mathrm{COO}^{-}+\mathrm{H}^{+}+2 \mathrm{H}_{2} \mathrm{O}
$$

Equation 5: Incorporation of $100 \% \mathrm{H}_{2}$ in Equation 3 into reductive acetogenesis

$$
\begin{gathered}
\mathrm{C}_{6} \mathrm{H}_{12} \mathrm{O}_{6}+0.153 \mathrm{H}_{2} \mathrm{O}+1.119 \mathrm{X} \longrightarrow 1.410 \mathrm{CH}_{3} \mathrm{COO}^{-} \\
+0.475 \mathrm{CH}_{3} \mathrm{CH}_{2} \mathrm{COO}^{-}+0.169 \mathrm{CH}_{3} \mathrm{CH}_{2} \mathrm{CH}_{2} \mathrm{COO}^{-} \\
+2.054 \mathrm{H}^{+}+1.022 \mathrm{CO}_{2}+0.0559 \mathrm{CH}_{4}+1.119 \mathrm{X}[2 \mathrm{H}]
\end{gathered}
$$

Equation 6: Generalization of Equation 5 for proportions of $\mathrm{H}_{2}$ incorporation into reductive acetogenesis between 0 and 1

$$
(0 \leq y \leq 1)
$$

$$
\begin{aligned}
& \mathrm{C}_{6} \mathrm{H}_{12} \mathrm{O}_{6}+(0.6-0.447 y) \mathrm{H}_{2} \mathrm{O}+1.119 X \longrightarrow \\
&(1.186+0.224 y) \mathrm{CH}_{3} \mathrm{COO}^{-}+0.475 \mathrm{CH}_{3} \mathrm{CH}_{2} \mathrm{COO}^{-} \\
&+0.169 \mathrm{CH}_{3} \mathrm{CH}_{2} \mathrm{CH}_{2} \mathrm{COO}^{-}+(1.831+0.224 y) \mathrm{H}^{+} \\
&+(1.469-0.447 y) \mathrm{CO}_{2}+0.895(1-y) \mathrm{H}_{2}+0.0559 \mathrm{CH}_{4} \\
&+1.119 \mathrm{X}[2 \mathrm{H}]
\end{aligned}
$$

Equation 7: Fermentation of glucose to acetate

$$
\mathrm{C}_{6} \mathrm{H}_{12} \mathrm{O}_{6}+2 \mathrm{H}_{2} \mathrm{O} \longrightarrow 2 \mathrm{CH}_{3} \mathrm{COO}^{-}+2 \mathrm{H}^{+}+2 \mathrm{CO}_{2}+4 \times[2 \mathrm{H}]
$$

Equation 8: Acetate to propionate shift in ruminal fermentation

$$
\mathrm{CH}_{3} \mathrm{COO}^{-}+\mathrm{CO}_{2}+3 \mathrm{H}_{2} \longrightarrow \mathrm{CH}_{3} \mathrm{CH}_{2} \mathrm{COO}^{-}+2 \mathrm{H}_{2} \mathrm{O}
$$

Equation 9: Incorporation of $100 \% \mathrm{H}_{2}$ in Equation 3 into propionate production

$$
\begin{gathered}
\mathrm{C}_{6} \mathrm{H}_{12} \mathrm{O}_{6}+0.00339 \mathrm{H}_{2} \mathrm{O}+1.119 \mathrm{X} \longrightarrow 0.888 \mathrm{CH}_{3} \mathrm{COO}^{-} \\
+0.773 \mathrm{CH}_{3} \mathrm{CH}_{2} \mathrm{COO}^{-}+0.169 \mathrm{CH}_{3} \mathrm{CH}_{2} \mathrm{CH}_{2} \mathrm{COO}^{-} \\
+1.831 \mathrm{H}^{+}+1.171 \mathrm{CO}_{2}+0.0559 \mathrm{CH}_{4}+1.119 \mathrm{X}[2 \mathrm{H}]
\end{gathered}
$$

Equation 10: Generalization of Equation 9 for proportions of $\mathrm{H}_{2}$ incorporation into propionate production between 0 and 1 $(0 \leq z \leq 1)$

$$
\begin{aligned}
& \mathrm{C}_{6} \mathrm{H}_{12} \mathrm{O}_{6}+(0.6-0.597 z) \mathrm{H}_{2} \mathrm{O}+1.119 \mathrm{X} \longrightarrow(1.186-0.298 z) \\
& \mathrm{CH}_{3} \mathrm{COO}^{-}+(0.475+0.298 z) \mathrm{CH}_{3} \mathrm{CH}_{2} \mathrm{COO}^{-} \\
& +0.169 \mathrm{CH}_{3} \mathrm{CH}_{2} \mathrm{CH}_{2} \mathrm{COO}^{-}+1.831 \mathrm{H}^{+} \\
& +(1.469-0.298 z) \mathrm{CO}_{2}+0.895(1-z) \mathrm{H}_{2}+0.0559 \mathrm{CH}_{4} \\
& +1.119 \mathrm{X}[2 \mathrm{H}]
\end{aligned}
$$

Equation 11: Theoretical fermentation of glucose to acetate and propionate

$$
\begin{aligned}
\mathrm{C}_{6} \mathrm{H}_{12} \mathrm{O}_{6} \longrightarrow & 0.667 \mathrm{CH}_{3} \mathrm{COO}^{-}+1.333 \mathrm{CH}_{3} \mathrm{CH}_{2} \mathrm{COO}^{-} \\
& +2 \mathrm{H}^{+}+0.667 \mathrm{CO}_{2}+0.667 \mathrm{H}_{2} \mathrm{O}
\end{aligned}
$$

